\title{
Bacterial GDGTs in Holocene sediments and catchment soils of a high Alpine lake: application of the MBT/CBT-paleothermometer
}

\author{
H. Niemann ${ }^{1}$, A. Stadnitskaia ${ }^{2}$, S. B. Wirth ${ }^{3}$, A. Gilli ${ }^{3}$, F. S. Anselmetti ${ }^{4}$, J. S. Sinninghe Damsté2,5 , S. Schouten ${ }^{2,5}$, \\ E. C. Hopmans ${ }^{2}$, and M. F. Lehmann ${ }^{1}$ \\ ${ }^{1}$ Dept. of Environmental Sciences, University of Basel, Bernoullistrasse 30, 4056 Basel, Switzerland \\ ${ }^{2}$ NIOZ Royal Netherlands Institute for Sea Research, Department of Marine Organic Biogeochemistry, \\ P.O. Box 59, 1790AB Den Burg, The Netherlands \\ ${ }^{3}$ Geological Institute, ETH Zurich, Sonneggstrasse 5, 8092 Zurich, Switzerland \\ ${ }^{4}$ Eawag, Swiss Federal Institute of Aquatic Science and Technology, Department of Surface Waters, \\ Überlandstrasse 133, 8600 Dübendorf, Switzerland \\ ${ }^{5}$ Department of Geosciences, Utrecht University, P.O. Box 80.021, 3508 TA, Utrecht, The Netherlands
}

Correspondence to: H. Niemann (helge.niemann@unibas.ch)

Received: 28 September 2011 - Published in Clim. Past Discuss.: 19 October 2011

Revised: 30 March 2012 - Accepted: 10 April 2012 - Published: 7 May 2012

\begin{abstract}
A novel proxy for continental mean annual air temperature (MAAT) and soil $\mathrm{pH}$, the MBT/CBTpaleothermometer, is based on the temperature $(T)$ and $\mathrm{pH}-$ dependent distribution of specific bacterial membrane lipids (branched glycerol dialkyl glycerol tetraethers - GDGTs) in soil organic matter. Here, we tested the applicability of the MBT/CBT-paleothermometer to sediments from Lake Cadagno, a high Alpine lake in southern Switzerland with a small catchment of $2.4 \mathrm{~km}^{2}$. We analysed the distribution of bacterial GDGTs in catchment soils and in a radiocarbondated sediment core from the centre of the lake, covering the past $11000 \mathrm{yr}$. The distribution of bacterial GDGTs in the catchment soils is very similar to that in the lake's surface sediments, indicating a common origin of the lipids. Consequently, their transfer from the soils into the sediment record seems undisturbed, probably without any significant alteration of their distribution through in situ production in the lake itself or early diagenesis of branched GDGTs. The MBT/CBT-inferred MAAT estimates from soils and surface sediments are in good agreement with instrumental values for the Lake Cadagno region $\left(\sim 0.5^{\circ} \mathrm{C}\right)$. Moreover, downcore MBT/CBT-derived MAAT estimates match in timing and magnitude other proxy-based $T$ reconstructions from nearby locations for the last two millennia. Major climate anomalies recorded by the MBT/CBT-paleothermometer are, for instance, the Little Ice Age ( $\sim 14$ th to 19th century) and
\end{abstract}

the Medieval Warm Period (MWP, 9th to 14th century). Together, our observations indicate the quantitative applicability of the MBT/CBT-paleothermometer to Lake Cadagno sediments. In addition to the MWP, our lacustrine paleo $T$ record indicates Holocene warm phases at about 3, 5, 7 and $11 \mathrm{kyr}$ before present, which agrees in timing with other records from both the Alps and the sub-polar North-East Atlantic Ocean. The good temporal match of the warm periods determined for the central Alpine region with north-west European winter precipitation strength implies a strong and far-reaching influence of the North Atlantic Oscillation on continental European $T$ variations during the Holocene.

\section{Introduction}

The assessment of climate variations in Earth's history is of paramount importance for our comprehension of recent and future climate variability. Instrumental climate data or historical records are, if at all, available for only the last few hundred years. Alternatively, geological archives containing climate-sensitive proxy indicators are used to reconstruct paleoclimate. Temperature $(T)$ is one of the master variables governing climate change and, as a consequence, large efforts have been made to reconstruct its variations in the past (IPCC, 2007). However, despite the successful 
reconstruction of pronounced $T$ changes during Earth's history (e.g. glacial-interglacial cycles) using proxy indicators in marine and terrestrial climate archives (e.g. sediments, ice cores and speleothems), well-constrained $T$ reconstructions for the Holocene, particularly for the continents, are comparably rare (Battarbee and Binney, 2008). This is partly caused by the fact that the Holocene is considered a rather stable time period with only subtle fluctuations in $T$ (IPCC, 2007), which are difficult to resolve. Consequently, the exact amplitude (Mann et al., 2009), as well as the geographical extent of Holocene $T$ variations (Davis et al., 2003; Renssen et al., 2009) remain uncertain. Holocene paleo $T$ records from the Swiss Alps, for instance, suggest that the Central European/Alpine Holocene climate displayed distinct, but not well-constrained climate transitions such as the Medieval Warm Period (MWP, 1200-600 calendar years before present (i.e. before 1950 - cal yr BP) and the Little Ice Age (LIA, 600-150 cal yr BP) (Heiri et al., 2004; Mangini et al., 2005, 2007; Larocque-Tobler et al., 2009, 2010b). Particularly for the early to middle Holocene prior to 2 cal kyr BP, estimates of absolute values for $T$ anomalies vary by several ${ }^{\circ} \mathrm{C}$ when comparing the available records. A second reason for our knowledge gap on continental Holocene $T$ variations is that paleoclimatological research traditionally focused on marine sediments. Typically, these records span very long time periods, but are rarely suitable to resolve sub-millennial time scales. As a consequence, lake sediments have become one of the prime targets for continental climate reconstructions (e.g. within the framework of the International Continental Drilling Project - ICDP). Similar to marine sediments, lacustrine sediment records can span long time periods, yet with much higher sedimentation rates. Thus, they allow establishing proxy-based records with a comparably high temporal resolution. However, lacustrine application of classical marine $T$ proxies is often problematic. The stable O-isotope composition of skeletal and non-skeletal deposits, for example, does not only reflect environmental $T$, but also depends on the hydrology of the lake system (Leng and Marshall, 2004). Similarly, pollen and skeletal remains have an undoubted potential for indicating environmental $T$ shifts, but floral and faunal community structure-based $T$ reconstructions can be compromised by ecological and migratory effects (Seppä and Bennett, 2003; Larocque-Tobler, 2010).

A promising complement to the set of existing proxy indicators for lake sediments are lipid biomarkers (Castañeda and Schouten, 2011). Microorganisms can modify the composition of their cellular membrane lipids to adapt membrane functionality to specific environmental parameters such as $T$ and $\mathrm{pH}$ (Hazel and Eugene Williams, 1990). This phenomenon provides the basis for biomarker paleothermometry. Well-established, lipid-based proxy indicators for sea surface temperature reconstructions, for instance, are the so-called TEX $\mathrm{T}_{86}$ (Schouten et al., 2002) and $\mathrm{U}_{37}^{k}$-indices (Brassell et al., 1986), but their application in lacustrine environments can be challenging. The relevant thaumarchaeotal glycerol dialkyl glycerol tetraethers (GDGTs) used for the $\mathrm{TEX}_{86}$-index as well as specific algal alkenones that are applied in the $\mathrm{U}_{37}^{k}$-index are not ubiquitous in lakes (Zink et al., 2001; Blaga et al., 2009; Toney et al., 2010; Powers et al., 2010). Also, the admixture of GDGTs from soil and sedimentary archaea can compromise the use of the $\mathrm{TEX}_{86}$-paleothermometer in lacustrine systems (Weijers et al., 2006b; Sinninghe Damsté et al., 2009; Tierney and Russell, 2009). The origin of GDGTs in sediments can be traced with the BIT-index, which relates branched GDGTs to crenarchaeol, assuming that these compounds are of soil and aquatic origin, respectively (Hopmans et al., 2004; Weijers et al., 2006b) (Eq. 1; see Appendix, Fig. A1 for structural information).

A viable alternative to proxy indicators that are based on lipids produced in the water column might be to use $T$ sensitive lipids that are produced in catchment soils only, and that are ultimately deposited and preserved within the lake sediments. A promising suite of lipids that could fulfil these requirements are three series of bacterial GDGTs, consisting of three structural isomers, with increasing degrees of methyl branching (Sinninghe Damsté et al., 2000; Weijers et al., 2006a) (structures of series I, II and III, respectively; Fig. A1 in the Appendix). Based on the analysis of globally distributed soil samples, Weijers and colleagues (2007a) developed transfer functions that relate the degree of the GDGT methylation (expressed in the methylation index - MBT, Eq. 2) and cyclisation (expressed in the cyclisation ratio - CBT, Eq. 3) to mean annual air temperature (MAAT, Eq. 4) and to soil pH (Eq. 5).

$$
\begin{aligned}
& \mathrm{BIT}=\frac{\mathrm{Ia}+\mathrm{IIa}+\mathrm{III} \mathrm{I}}{\mathrm{Ia}+\mathrm{IIa}+\mathrm{IIIa}+\mathrm{IV}} \\
& \mathrm{MBT}=\frac{\mathrm{Iabc}}{\mathrm{Iabc}+\mathrm{IIabc}+\mathrm{IIIabc}} \\
& \mathrm{CBT}=-\log \frac{\mathrm{Ib}+\mathrm{IIb}}{\mathrm{Ia}+\mathrm{IIa}}
\end{aligned}
$$

$\mathrm{MAAT}=\frac{\mathrm{MBT}-0.187 \mathrm{CBT}-0.122}{0.02}$

$\mathrm{pH}=-\frac{\mathrm{CBT}-3.33}{0.38}$

Several attempts have recently been made to apply the GDGT-based proxies to lacustrine sediment records (Sinninghe Damsté et al., 2009; Tierney and Russell, 2009; Blaga et al., 2010; Bechtel et al., 2010; Tierney et al., 2010a, b; Tyler et al., 2010; Zink et al., 2010; Fawcett et al., 2011; 
Loomis et al., 2011; Pearson et al., 2011). All studies so far (mostly targeting surface sediments) revealed that branched GDGTs occur ubiquitously in lake sediments and often represent the most abundant sedimentary GDGTs (Sinninghe Damsté et al., 2009; Tierney and Russell, 2009; Tyler et al., 2010; Blaga et al., 2010; Bechtel et al., 2010; Tierney et al., 2010a; Loomis et al., 2011; Pearson et al., 2011). However, when using the transfer function proposed by Weijers et al. (2007a), which was originally developed for soils, calculated MBT/CBT-indices translated into absolute MAAT values, which seemed to systematically underestimate the actual MAAT. While we are only at the beginning to understand the exact biogeochemical mechanisms that can lead to such offsets, admixture of branched GDGTs produced in a lake system (in situ) has been discussed as a likely mechanism that would lead to changes of the soil-derived lipid pattern in lacustrine sediments (Sinninghe Damsté et al., 2009; Tierney and Russell, 2009; Blaga et al., 2010; Tierney et al., 2010a, 2012).

The main goal of this study is to expand the existing data set of lacustrine MBT/CBT records in order to (i) "ground truth" the MBT/CBT-paleothermometer for its application in sediments and catchment soils of a high Alpine lacustrine setting and to (ii) establish a Holocene temperature and soil $\mathrm{pH}$ record for the Swiss Alps. As a study area, we selected the small, high Alpine Lake Cadagno (Switzerland) which has a small, well-defined catchment and has a high potential for the preservation of sedimentary organic matter (OM). Our MBT/CBT-derived time series of MAAT and soil $\mathrm{pH}$ sediment records for the Lake Cadagno catchment compares well with instrumental and independent proxy data, indicating subtle but significant Holocene climatic shifts in the Alpine realm and Europe.

\section{Material and methods}

\subsection{Site description}

Lake Cadagno is a relatively small (surface area: $0.26 \mathrm{~km}^{2}$, maximum depth: $21 \mathrm{~m}$ ), Alpine lake located at $1921 \mathrm{~m}$ above sea level (a.s.l.) in the Piora Valley in the south-central part of Switzerland (Fig. 1). Its high Alpine setting results in a low MAAT of $\sim 0.5^{\circ} \mathrm{C}$ (see below). The small catchment area of $\sim 2.4 \mathrm{~km}^{2}$ (estimates from a digital elevation model, Swisstopo) is defined by the almost crater-like setting of Lake Cadagno: a mountain range frames the lake from $\mathrm{W}$ to $\mathrm{NE}$, and a moraine separates it from Lake Ritom's catchment in the south and the Piora Valley to the east. Due to the steep topography north of the lake, snow avalanches reach the lake shore on a frequent basis. The peak of Mount Pizzo Taneda (2667 ma.s.1.) represents the highest elevation within the Lake Cadagno catchment, but areas above $2200 \mathrm{~m}$ a.s.l. are rarely covered by soils. At lower elevations, the lake's catchment area is mostly covered by Alpine grassland, and to a

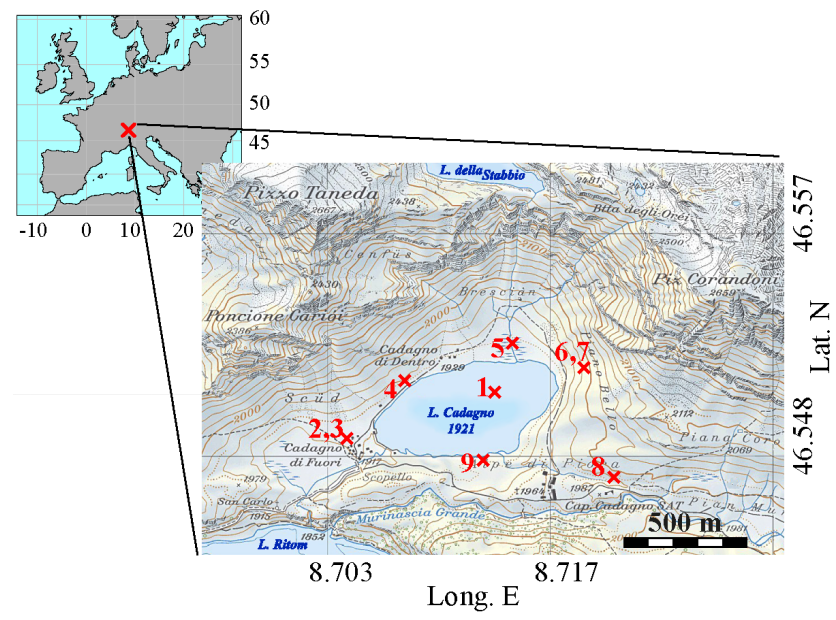

Fig. 1. Lake Cadagno and its crater-like shaped catchment area. Sampling positions of sediment coring (Site 1) and soil collection (Sites 2-9) are indicated (topographic map modified from Swisstopo).

lesser degree by conifer and blueberry shrubs, or swamps. The more gentle slopes in the vicinity of the lake are used as cattle pasture. The hydrologic balance is controlled by inflow from several small creeks, subaquatic groundwater discharge from the dolomite/gypsum bedrock, and the outflow to Lake Ritom in the SW. The constant supply of solute-rich (e.g. $\mathrm{SO}_{4}^{2-}$ ) groundwater from subaquatic springs has led to water column stabilisation and, ultimately, to meromixis with a permanent but seasonally dynamic chemocline between 9 and $14 \mathrm{~m}$ water depth (Del Don et al., 2001). The lake's monimolimnion is anoxic and characterised by high sulfide concentrations (up to $1 \mathrm{mM}$ ) derived from microbial sulfate reduction (Hanselmann and Hutter, 1998). We assume that most soil organic matter in the lake sediments originates from catchment slopes north of the lake at elevations between 1900-2200 ma.s.l., washed in by physical erosion through snow avalanches, during flood events and by fluvial transport.

\subsection{Sampling}

Lake sediment cores and soil samples were collected during two sampling campaigns in September 2009 and May 2010, respectively. For sediment coring, a platform was anchored at the deepest part of the lake (Fig. 1, Table 1) and two composite piston cores $(10.5 \mathrm{~m}$, Core 1 and $9.5 \mathrm{~m}$, Core 2) were recovered using an UWITEC percussion-piston coring system. The composites also comprised short $(1 \mathrm{~m})$ gravity cores with undisturbed surface sediments that were retrieved at the same location. Core 1 was dedicated to stratigraphic and dating analyses, and Core 2 was used for organic geochemical analyses. Immediately after coring, the core for organic geochemical analysis was cut longitudinally into halves. One core half was then sub-sampled for lipid 
Table 1. Sediment and soil samples recovered from Lake Cadagno and its catchment area.

\begin{tabular}{crrrrr}
\hline $\begin{array}{c}\text { Sampling } \\
\text { position }\end{array}$ & Lat $\left({ }^{\circ} \mathrm{N}\right)$ & Long $\left({ }^{\circ} \mathrm{E}\right)$ & $\begin{array}{r}\text { Sample } \\
\text { type }\end{array}$ & $\begin{array}{r}\text { Profile } \\
\text { depth }(\mathrm{cm})\end{array}$ & $\begin{array}{r}\text { Sampling } \\
\text { interval }(\mathrm{cm})\end{array}$ \\
\hline 1 & 46.5507 & 8.7139 & $\begin{array}{r}\text { lake sediments } \\
\text { (short core) } \\
\text { lake sediments }\end{array}$ & surface -96 \\
& & & & 5 \\
& & & somposite long core) & surface -870 & 10 \\
2 & 46.5491 & 8.7044 & soil & surface & bulk \\
3 & 46.5490 & 8.7044 & soil (profile) & surface -60 & 15 \\
4 & 46.5506 & 8.7072 & soil (profile) & surface -60 & 15 \\
5 & 46.5526 & 8.7145 & creek soil /sediment & surface & bulk \\
6 & 46.5523 & 8.7175 & soil & surface & bulk \\
7 & 46.5523 & 8.7176 & soil & surface -96 & bulk \\
8 & 46.5470 & 8.7208 & soil (profile) & surface -30 & 15 \\
9 & 46.5480 & 8.7129 & soil (profile) & surface -45 & 15 \\
\hline
\end{tabular}

analyses (see Sect. 2.3) and the other one was used for lithologic description and photo documentation. For lipid analysis, sediment intervals of 5 (gravity) and $10 \mathrm{~cm}$ (piston cores) length were continuously sub-sampled throughout the core sections, and stored frozen $\left(-20^{\circ} \mathrm{C}\right)$ in pre-cleaned glass jars until further treatment in our home laboratories. The core for stratigraphic and dating analysis (Core 1) was opened and described after return to our laboratories. Similar to the core used for organic geochemical analysis, we photodocumented and described the sedimentology as well as sampled wood particles and terrestrial macrofossils at distinct sediment depths for ${ }^{14} \mathrm{C}$-AMS measurements (Sect. 2.6).

Soil samples were collected from several locations within the lake's catchment area (Fig. 1, Table 1), using a small shovel (bulk surface soils) or a hand-operated soil corer. Soil profiles were sub-sampled with a vertical resolution of $15 \mathrm{~cm}$. Just as sediments, soil samples were frozen in precleaned glass jars until further treatment.

\subsection{Lipid analysis}

Prior to lipid extraction, sediment and soil samples were freeze-dried, and sub-samples were homogenised. Total lipid extracts (TLEs) were obtained by accelerated solvent extraction (ASE, DIONEX 200) from about 3-5 g freeze-dried sediments or $\sim 10 \mathrm{~g}$ of freeze-dried soil, as specified previously (Weijers et al., 2007a). $0.1 \mu \mathrm{g}$ of the $\mathrm{C}_{46}$-GDGT internal standard (Huguet et al., 2006) was added to the TLE before concentration under a gentle stream of $\mathrm{N}_{2}$ to about $1 \mathrm{ml}$. Elemental sulfur in the TLE was then removed by treatment with activated $\mathrm{Cu}$. The TLE was subsequently separated over an activated $\mathrm{Al}_{2} \mathrm{O}_{3}$ column using (i) ethyl acetate and (ii) dichloromethane:methanol $(95: 5, \mathrm{v} / \mathrm{v})$ as solvents, yielding (i) a neutral and (ii) a polar fraction, respectively. The polar fraction (containing the GDGTs) was dried under $\mathrm{N}_{2}$, re-dissolved in hexane:isopropanol (99:1, v/v), filtered through a $0.45 \mu \mathrm{m}$ PTFE syringe filter and condensed to a total concentration of $\sim 2 \mathrm{mg}$ of dried polar fraction per $\mathrm{ml}$ hexane:isopropanol mixture. GDGTs were analysed by high performance liquid chromatography/atmospheric pressure chemical ionisation mass spectrometry (HPLC/APCI$\mathrm{MS}$ ) in single ion monitoring mode according to the analytical setup and instrumental specifications described by Schouten et al. (2007). Peak areas of $(\mathrm{M}+\mathrm{H})^{+}$-ions of GDGTs were determined by manual integration using the HP Chemstation software package. MBT- and CBT-indices as well as corresponding MAAT and $\mathrm{pH}$ values were calculated according to Eqs. (1)-(4). Reproducibility (based on duplicate sample analyses and repeated integration) was 0.002 for the MBT- and 0.01 for the CBT-index, translating into an analytical error of ca. $\pm 0.1^{\circ} \mathrm{C}$ for MAAT and $\pm 0.1 \mathrm{pH}$ units. Together with the branched GDGTs, we also measured crenarchaeol to determine BIT values (Eq. 1), as described previously (Hopmans et al., 2004). Analyses were carried out at the NIOZ organic geochemical laboratory (Texel, The Netherlands).

\subsection{Environmental parameters}

Modern MAAT at Lake Cadagno was assessed using instrumental data series for nearby locations published in the MeteoSwiss database (www.meteoschweiz.admin.ch/web/en/ climate/climate_today/homogeneous_data.html). At Piotta, which is located in the valley just below Lake Cadagno (4.5 km distance; $990 \mathrm{~m}$ a.s.1.), MAAT is $7.2^{\circ} \mathrm{C}$ (mean data 1961-1990). Relatively close-by but at lower altitudes are the long-term meteorological observatories (MeteoSwiss) in Lugano (273 ma.s.1., MAAT $=11.6^{\circ} \mathrm{C}$, mean data $1961-$ 1990) and Locarno (366 $\mathrm{m}$ a.s.1., MAAT $=11.5^{\circ} \mathrm{C}$, mean data 1961-1990). The lapse rate in the area is hence 0.6 to $0.7^{\circ} \mathrm{C}$ $100 \mathrm{~m}^{-1}$, which translates into a MAAT of $\sim 1{ }^{\circ} \mathrm{C}$ at an elevation of $1921 \mathrm{~m}$ a.s.l., the altitude of Lake Cadagno. Based on similar records, MAAT was previously estimated for the Lake Cadagno area to be $0^{\circ} \mathrm{C}$ (Schürmann et al., 2002), so 
that we assume here an average MAAT of $\sim 0.5^{\circ} \mathrm{C}$. Soil $\mathrm{pH}(\mathrm{pH}=4$ to 7$)$ was determined by measuring the $\mathrm{pH}$ in a soil/ $\mathrm{H}_{2} \mathrm{O}$ mixture $(5 \mathrm{~g}$ of dried homogenized soil per $12.5 \mathrm{ml}$ DI) using a Mettler Toledo SevenMulti $\mathrm{pH}$ probe.

\subsection{Independent proxies}

To "ground truth" the MBT/CBT-derived climate reconstructions, we compared our data with climate reconstructions based on independent climate proxies. In order to avoid biasing effects that may arise from geographical variations, we focused on regional data sets. These are based on O-isotope-derived $T$ reconstructions from stalagmites in the Spannagel Cave, Central Alps (Mangini et al., 2005, 2007 ) and $T$-dependent chironomid population dynamics in Lake Silvaplana (Larocque-Tobler et al., 2010a), as well as Lake Egelsee (Larocque-Tobler et al., 2010b; LarocqueTobler, 2010) in the central and northern Alps, respectively. In addition, we present our $T$ record in the context of larger/hemispherical-scale climate variations through comparison with Holocene sea surface $T$ variations in the NE Atlantic (Thornalley et al., 2009) and with reconstructions of the North Atlantic Oscillation (NAO) from Europe (Nesje et al., 2001; Trouet et al., 2009). Whenever possible, we used original data available at the World Data Center for Paleoclimatology (http://ncdc.noaa.gov/paleo/recons.html).

\subsection{Core chronology}

The sediment core chronology was developed for Core 1 using nine AMS radiocarbon ages derived from wood and terrestrial macrofossils (Table 2), providing age points that are unaffected by the hard water dating error (Deevey et al., 1954). Analyses were carried out at the AMS $-{ }^{14} \mathrm{C}$ laboratory at the ETH Zurich, Switzerland. The radiocarbon ages were converted to calendar years before 1950 (cal yr BP) using the online calibration software OxCal 4.1 (https://c14.arch. ox.ac.uk/oxcal/OxCal.html) (Bronk Ramsey, 2009) and the Intcal09 calibration curve (Reimer et al., 2009). The agedepth model of Core 1 was constructed by applying a cubic spline interpolation between the dating points using the Clam software package (Blaauw, 2010). The core used for organic geochemical sampling (Core 2) was dated through accurate stratigraphic correlation with the AMS ${ }^{14} \mathrm{C}$-dated master core (Core 1) using 68 visually identified tie-points (dots in Fig. 2). Sample material collected from slump deposits was not considered for age-depth modelling and paleoclimate reconstructions (see below).

\section{Results}

\subsection{Sedimentological units and age-depth model}

A detailed discussion of the lithology and depositional units and their paleoenvironmental significance, as well as details

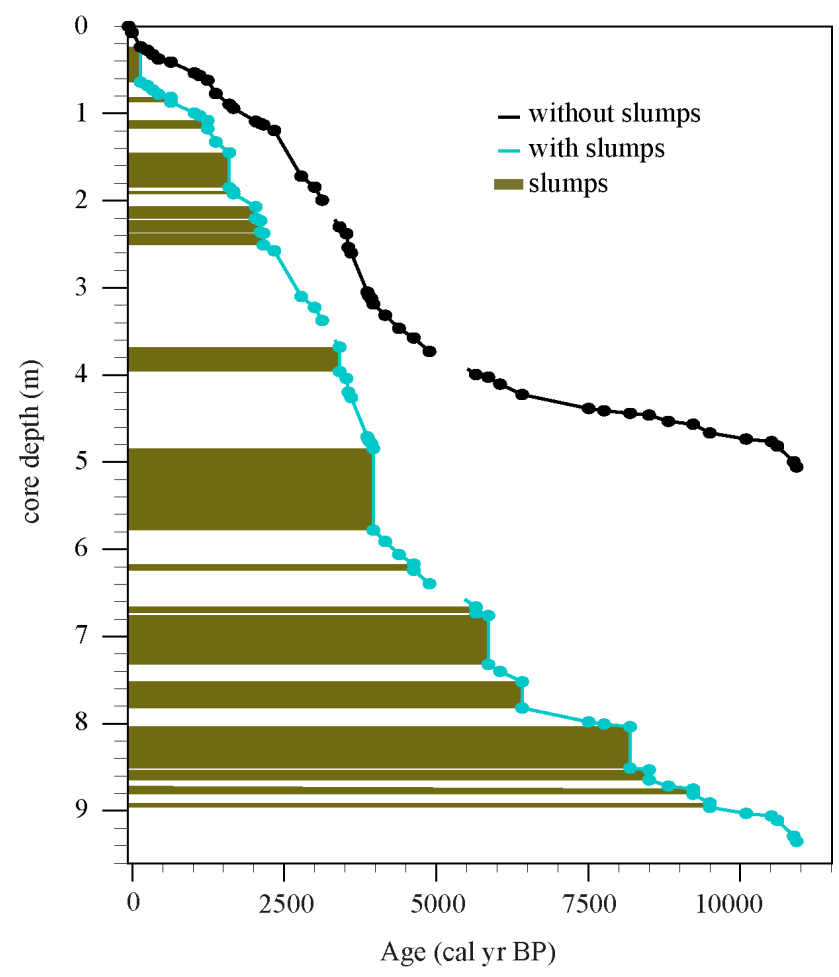

Fig. 2. Age-depth model for Core 2. The age-depth model for the Holocene sediment sequence of Lake Cadagno was developed for Core 1 from nine calibrated radiocarbon ages of terrestrial macrofossils and wood fragments (Table 1) and transferred to Core 2 on the basis of 68 visual-identified tie-points (tie-points are indicated as dots). Almost half of the recovered composite core consists of slump deposits (brown sections) intercalating regular sediments. The cyan curve shows the age-depth model including all deposits; for the black curve, slump deposits were excluded from the record.

on the age-depth modelling will be provided elsewhere (Wirth et al., 2012). Briefly, the Lake Cadagno sediments were found to consist of regular, laminated background sediments intercalated with flood layers and slump deposits, the latter of which were sometimes extensive with a thickness of up to $71 \mathrm{~cm}$ (Fig. 2). Slump deposits were identified based on their characteristic graded particle size distribution, with sandy particles at the base and organic-rich and silty to clayey sediments at the top. Moreover, the deposits often showed clear deformation structures, such as oblique, thrusted and/or upside down-oriented sediment layers, sometimes with embedded mud clasts. Flood layers, in contrast, were characterised by a higher fraction of mineral grains and contained mostly terrestrial organic material. In general, flood layers were also thinner than slump deposits (sub-mm to up to $13 \mathrm{~cm}$ ).

Figure 2 illustrates the down-core distribution of slump deposits intercalating regular sediments and flood layers. In the age depth model, the slump deposits are shown as layers without any age information, because slump deposits 
Table 2. Radiocarbon dates of terrestrial organic material collected from various sediment depths. All radiocarbon dates were converted to calendar years before 1950 (cal yr BP). Ages derived from sample material in slump deposits were not considered for age-depth modelling (ages denoted with asterisks).

\begin{tabular}{lrlrrr}
\hline Lab code & $\begin{array}{l}\text { Composite } \\
\text { depth }(\mathrm{cm})\end{array}$ & $\begin{array}{l}\text { Sample } \\
\text { material }\end{array}$ & $\begin{array}{r}{ }^{14} \mathrm{C} \text { age } \\
\left({ }^{14} \mathrm{C} \text { yr BP }\right)\end{array}$ & $\pm 1 \sigma$ & $\begin{array}{r}\text { Calibrated age } \\
(\text { cal yr BP }), 2 \sigma-\text { range }\end{array}$ \\
\hline ETH-42351 & 102.5 & terr. macrofossils & 1255 & 60 & $1056-1295$ \\
ETH-39236 & 223 & wood & 2035 & 35 & $1898-2112$ \\
ETH-41051 & 337.5 & terr. macrofossils & 3015 & 35 & $3079-3338$ \\
ETH-39237 & 419.5 & wood & 3305 & 35 & $3452-3630$ \\
ETH-41052 & 652 & wood & 4595 & 35 & $5068-5460$ \\
ETH-39238 & 696 & wood & 5035 & 35 & $5663-5899^{*}$ \\
ETH-41053 & 778.5 & terr. macrofossils & 8015 & 35 & $8765-9012^{*}$ \\
ETH-42352 & 798 & wood & 6450 & 35 & $7291-7430$ \\
ETH-41054 & 871.5 & wood & 8055 & 35 & $8776-9079$ \\
ETH-44254 & 909.7 & terr. macrofossils & 9340 & 35 & $10431-10667$ \\
ETH-39238 & 919.5 & wood & 9630 & 45 & $10776-11180$ \\
\hline
\end{tabular}

represent mobilised, mixed and re-deposited sediments from shallower parts of the lake that were transported to the deepest lake area. Hence, they provide sediments out of chronological sequence with the over- and underlying sediments (see Table 2). We consequently corrected the composite sediment depth for slump deposits, yielding a $5 \mathrm{~m}$-long composite core used for paleoclimate reconstructions (Fig. 2, black curve). As the deposition of slumps was probably nonerosive in the deepest basin, their removal should not create hiatuses. A continuous sediment succession can thus be assumed, with exception of two gaps between the three separate piston core sections (translating into hiatuses of several centuries around 3150 and $5250 \mathrm{cal} \mathrm{yr} \mathrm{BP;} \mathrm{Figs.} \mathrm{2,} \mathrm{4a} \mathrm{and} \mathrm{6).}$

\subsection{GDGT distribution in sediments and soils}

All sediment and soil samples contained branched GDGTs. Generally, branched GDGTs without cyclopentyl moieties (Series a; see Appendix Fig. A1 for a structural representation) were most abundant, followed by compounds with one or two rings (Series b and c, respectively) (Fig. 3). The composition of GDGTs in most soil samples ( $n=11$, i.e. all samples collected from positions 2, 3, 5-7 and 9; Fig. 1) was very similar to that in surface sediments (top section of the short core, see Appendix Tables A1, A2). MBT values ranged between 0.18 to 0.39 , with an average of $0.28 \pm 0.07$ standard deviation $\left(S_{\mathrm{D}}\right)$, and CBT values between 0.28 and 1.41 (average $=0.85 \pm 0.41 S_{\mathrm{D}}$ ). Variations in the MBT or CBT ratios did not seem to be associated with soil type, nor could significant trends be discerned within vertical soil profiles. Soils from sampling Sites 2 and 3 were taken from a meadow, Site 5 corresponds to the riverbed of a creek, Sites 6 and 7 represent soils from the upper edge of a snow avalanche with admixture of eroded soil, and Site 9 samples represent a wet/swampy soil. Only soils from sampling Sites $4(n=4)$ and $8(n=2)$, which were taken from a meadow (similar to

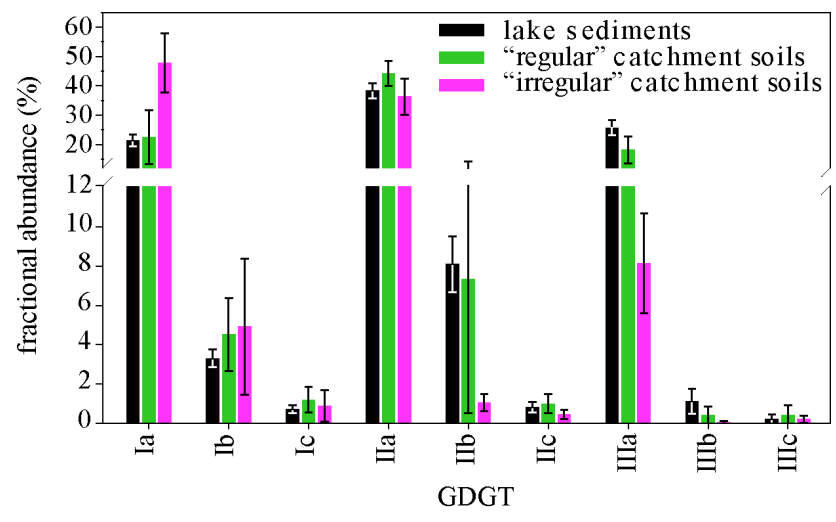

Fig. 3. Relative abundance of GDGTs comprised in the MBT/CBT ratios from lake sediments and soils. Series a GDGTs (i.e. without cyclopentane moieties) are most abundant, followed by Series $\mathrm{b}$ and $\mathrm{c}$ (see Fig. A1 in the Appendix for structural information). Based on the strong differences in GDGT abundance, we defined two soil types. The distribution of GDGTs in most soil samples (regular soils, $n=11$ ) was very similar to the uppermost lake sediments. Only soils from sampling positions $4(n=4)$ and $8(n=2)$ (irregular soils) showed considerably different abundance patterns (i.e. relatively high amounts of compound Ia and low amounts of compounds IIb and IIIa). Soil profiles did not reveal recognisable trends in either MBT or CBT ratio with depth.

the habitat at sampling position 2 and 3) - in the following referred to as "irregular" soils - showed a considerably different GDGT abundance pattern when compared to lake sediments and the "regular" soils; these particular soils contained high fractional abundances of GDGT Ia and low amounts of compounds IIb and IIIa (Fig. 3). The "irregular" soils displayed average MBT values of $0.54 \pm 0.08 S_{\mathrm{D}}$ and average CBT values of $1.19 \pm 0.22 S_{\mathrm{D}}$, with maximum values of 0.66 and 1.40 , and minimum values of 0.42 and 0.80 for MBT and CBT, respectively. Whereas the MBT/CBT ratios 
in the surface sediment sample and "regular" soils translate (using the Weijers et al. (2007a) global soil calibration) into reasonably low MAAT values of 1.5 (Fig. $4 \mathrm{a}, \mathrm{e}$ ) and $0.1{ }^{\circ} \mathrm{C}$ \pm 1.2 , respectively (i.e. within the range of instrumental measurements of $\sim 0.5^{\circ} \mathrm{C}$ ), MBT/CBT-derived MAAT estimates based on the "irregular" soil samples were, with $9.7^{\circ} \mathrm{C} \pm 4.1$ $S_{\mathrm{D}}$, significantly higher (f-test, $p<0.05$ ). CBT-based $\mathrm{pH}$ estimates from both "regular" and "irregular" soils overestimated measured $\mathrm{pH}$ values by $\sim 0.9$ on average, and in the extreme by $1.5 \mathrm{pH}$ units (Fig. 5), which is just outside the calibration error of the CBT proxy (ca. $1 \mathrm{pH}$ unit; Weijers et al., 2007a). In order to address the possibility of contaminating effects of the "irregular" soil sites through cattle pasturing, we also analysed 2 samples of cow faeces, but these were found to contain only trace amounts of the target GDGTs (data not shown). Crenarchaeol was present in all analysed soil samples (albeit at lower concentration than in sediments), and BIT values were generally high (average: $\left.0.99 \pm 0.01 S_{\mathrm{D}}\right)$.

In the lake sediments, the composition of the lipid extracts was very complex. For four of the lake sediment samples, this led to high background levels during HPLC analyses, which compromised chromatographic resolution. In these cases, the GDGT distributions could not be determined adequately and, as a consequence, they were not considered for paleoclimate reconstructions (resulting in $<200 \mathrm{yr}$ gaps in the climate records; Figs. 4a, e and 6). The distribution of GDGTs varied with depth in the sediment core. MBT and CBT values ranged from 0.18 to 0.29 and 0.37 to 0.88 , respectively, with average values of $0.26 \pm 0.02 S_{\mathrm{D}}$ (MBT) and $0.72 \pm 0.09 S_{\mathrm{D}}(\mathrm{CBT})(n=47)$. In contrast to MBT/CBTindices, BIT-indices did not show any systematic variation with sediment depth and were generally high, averaging at $0.97\left( \pm 0.04 S_{\mathrm{D}}\right)$, i.e. slightly lower than in soils. Only the four lowermost samples (i.e. sediments older than $10514 \mathrm{cal}$ yr BP) showed lower BIT values of 0.77 to 0.88 .

\section{Discussion}

\subsection{Origin of GDGTs in Lake Cadagno sediments}

The MBT/CBT-indices are based on the distribution of branched GDGTs of presumably soil bacterial origin (Weijers et al., 2007a), probably Acidobacteria (Weijers et al., 2009; Sinninghe Damsté et al., 2011). Consequently, the successful application of the MBT/CBT-paleothermometer to lake sediments requires an unbiased transfer of the soil GDGT signature into the lacustrine record. An important factor, which has likely contributed to the discordance between estimated and actual $T$ observed in previous studies, is the in situ production of the relevant GDGTs within the lake system. Admixed to the soil-derived compounds, autochthonous GDGTs would obviously change the primary, soil-derived GDGT signal (Sinninghe Damsté et al., 2009;
Tierney and Russell, 2009; Blaga et al., 2010; Tierney et al., 2010a). As for Lake Cadagno, we found that "regular" soils and the surface sediments showed similar GDGT patterns. Only the fractional abundances of branched GDGTs IIb and, to a lesser degree, Ib display some discrepancies. Yet, the influence of these GDGTs on the estimation of MAAT is relatively small (see Eqs. 1 and 4). The good match of soil- and sediment-derived patterns of branched GDGT argues for a common origin of these compounds. A substantial contribution of branched GDGTs originating from in situ production in the lake water column and/or in sediments, on the other hand, appears unlikely, as this would imply that the pattern of GDGTs produced in the lake was similar to that in the soils. The application of the MBT/CBT-paleothermometer in lakes with elevated fluxes of in situ produced branched GDGTs is problematic and requires, if possible at all, a correction for authigenic production of the target compounds. This aspect has been addressed in recent studies by developing alternative calibrations based on the distribution of branched GDGTs in modern (surface) lake sediments and not in soils (Zink et al., 2010; Tierney et al., 2010a; Pearson et al., 2011). However, when applied to Lake Cadagno surface sediments, these lake-specific transfer functions translate into unreasonably high values, overestimating instrumental MAAT by $\sim 6$ (Tierney et al., 2010a) to $9^{\circ} \mathrm{C}$ (Zink et al., 2010), which provides additional indication that the distributions of branched GDGTs in Lake Cadagno's sediments is not markedly influenced by in situ production. A dominantly allochthonous source of branched GDGTs in the lake sediments is further indicated by the equal or slightly higher BIT values in soils compared to sediments. In situ production of branched GDGTs and their addition to the soil-derived GDGT pool would result in increased BIT-indices in sediments (compared to a scenario with no in situ production) (see Eq. 1; Sinninghe Damsté et al., 2009). This is apparently not the case for Lake Cadagno. Also, absolute concentrations of branched GDGTs were very similar in soil and sediment samples (data not shown), again arguing against substantial addition of in situ produced GDGTs to the sediment pool.

Alteration of branched GDGT distribution during (early) diagenesis, e.g. due to microbial degradation, may also have a biasing effect on the sedimentary GDGT signatures, an aspect that has not been investigated in detail for bacterial GDGTs in limnic environments. Research on alkenones and archaeal GDGTs could show a rapid decrease in concentration of these compounds, particularly during oxic conditions, which sometimes led to alteration of the lipid pattern (Hoefs et al., 1998; Sinninghe Damsté et al., 2002; Schouten et al., 2004; Huguet et al., 2009; Zabeti et al., 2010). Similar to the argumentation against in situ production, the congruent GDGT distribution in soils versus surface sediments suggests that early diagenesis is not an important process at Lake Cadagno.

It remains unclear as to why in situ production (or possibly early diagenesis) may have a strong biasing effect 

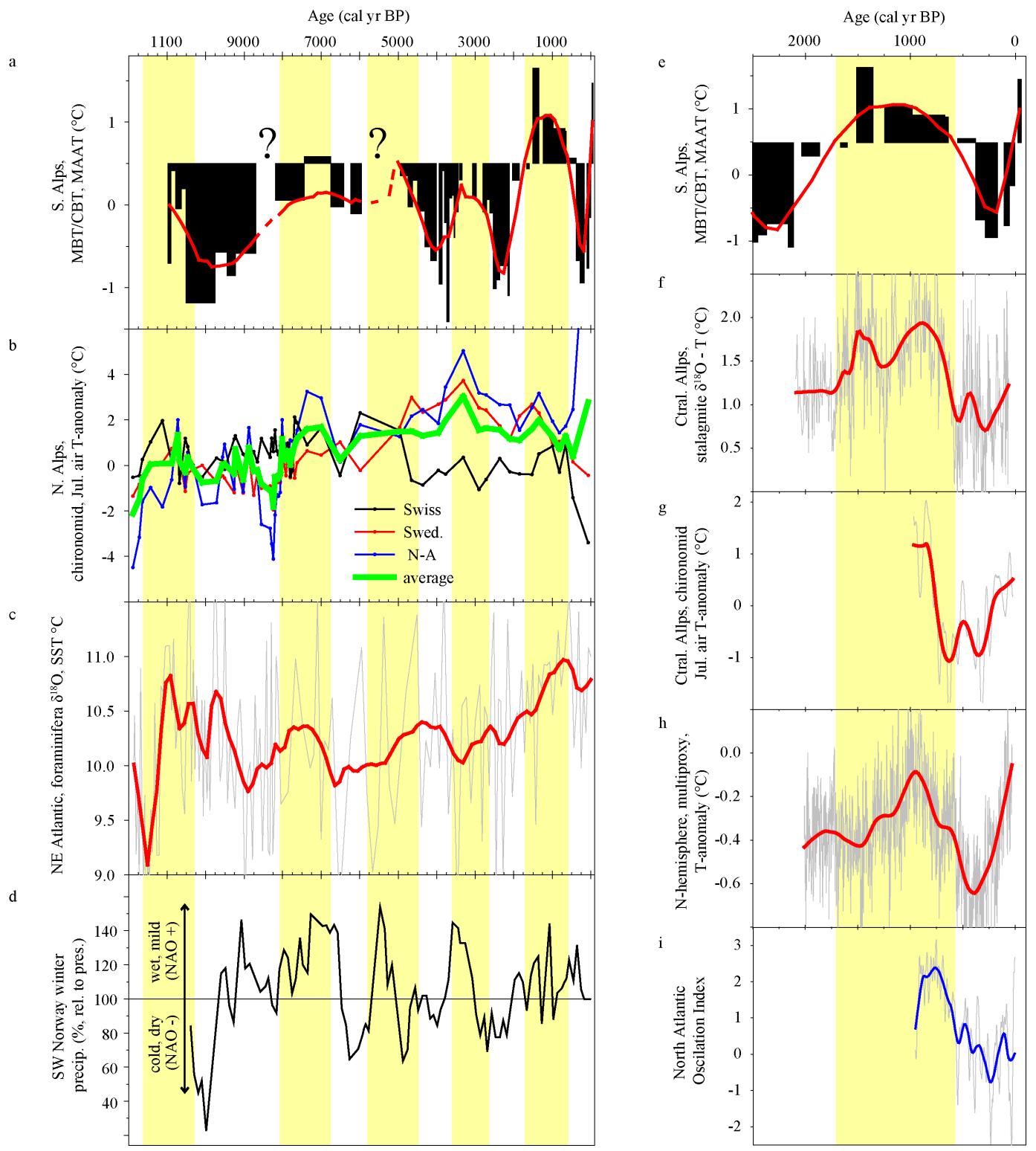

Fig. 4. MBT/CBT-derived MAAT estimates for the Holocene epoch in comparison to independent proxy records. Temperature highs determined from the MBT/CBT record are highlighted in yellow. (a) Lake Cadagno MBT/CBT-based paleotemperature. Bars represent raw data of MBT/CBT-paleothermometry (temporal resolution is indicated by bar width) and the red curve a low-pass filter (bisquare, 0.15). Temporal hiatuses in the record are caused by discontinuities in the composite (dashed line section) and samples that were removed from the record (because the relevant GDGTs could not be resolved appropriately or the sample contained substantial amounts of slump deposit material). (b) July air $T$ anomaly at Lake Egelsee, northern Alps, as estimated from chironomid communities using different transfer functions, which were developed for Switzerland, Sweden and North America (Larocque-Tobler et al., 2010b; Larocque-Tobler, 2010; raw data courtesy of Isabelle Laroque-Tobler). (c) Sea surface temperatures of the sub-polar NE Atlantic estimated from foraminiferal $\delta^{18} \mathrm{O}$ signatures (Thornalley et al., 2009). (d) Winter precipitation in West Norway, indicating variations in the North Atlantic Oscillation (NAO), redrawn and modified from Nesje et al. (2001). (e) Sectional enlargement of MBT/CBT-based MAAT estimates of the last 2500 yr in comparison to (f) temperature estimates for the Central Alps based on $\delta^{18} \mathrm{O}$ variations of stalagmites (Mangini et al., 2005), (g) July air temperature anomaly in the Central Alps estimated from chironomid assemblages (Larocque-Tobler et al., 2010a), (h) Northern Hemisphere temperature anomaly reconstructed from a multiproxy record (Moberg et al., 2005) and (i) NAOI estimated from a tree-ring-based drought reconstruction for Morocco and a speleothem-based precipitation proxy for Scotland (Trouet et al., 2009). Ages are presented as calendar years before 1950 (cal yr BP). Raw data from (c) and (f-i) (grey lines) are available at the World Data Center for Paleoclimatology, Boulder, CO, USA (ncdc.noaa.gov/paleo/recons.html). Raw data were harmonised by applying low-pass filters (bisquare, 0.075, (c); bisquare 0.15, red and blue lines, $(\mathbf{f}-\mathbf{i})$ ). MBT/CBT-based MAAT reconstructions show a good match in timing and amplitude to independent $T$ estimates for the last 2 millennia (f-h). Most of the major $T$ anomalies recorded by the MBT/CBT-paleothermometer (1, 3, 5, 7 and 11 kyr BP) are also visible in chironomid-based $T$ estimates for the northern Alps (b) and sea surface temperatures of the NE Atlantic (c). All temperature highs after ca. 8 cal. kyr BP agree well in timing with maxima in the NAO (d and i). 


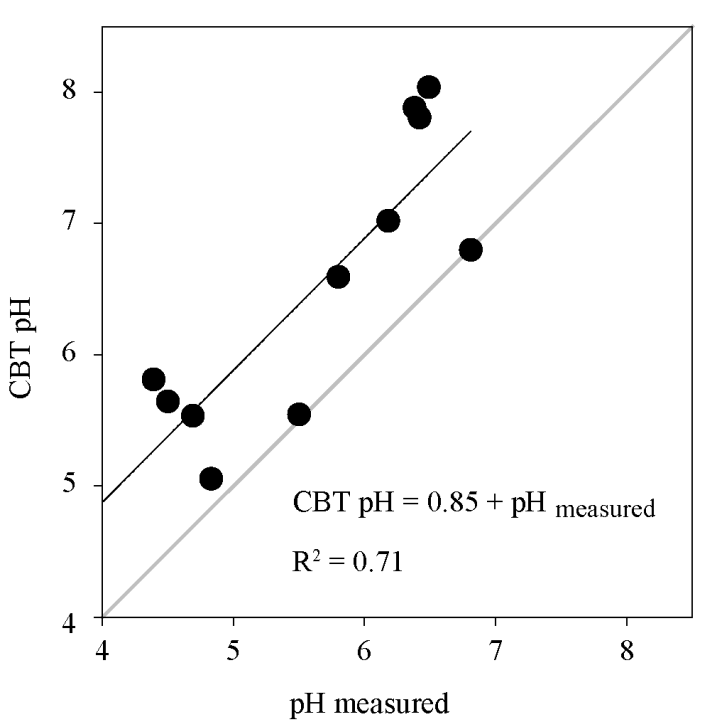

Fig. 5. pH measurements and CBT-based pH estimates in soils. Soil $\mathrm{pH}$ measurements versus CBT-based $\mathrm{pH}$ estimates indicate that the estimated $\mathrm{pH}$ is high but within the range of measured $\mathrm{pH}$ values (a 1:1 relation is indicated by the grey line).

on the distribution of bacterial GDGTs in other lake systems, while it appears to be of lesser importance for Lake Cadagno. More analyses are required to investigate possible mechanisms/pathways that may compromise the soil-derived GDGT signals in greater detail. To date, we can only speculate that the particular environmental conditions in Lake Cadagno's water column and sediments prevent the in situ production or diagenetic alteration of branched GDGTs. It is, in particular, the high sulfide concentration that distinguishes Lake Cadagno from other meromictic lakes, where indications for in situ production of bacterial GDGTs were found (Sinninghe Damsté et al., 2009; Bechtel et al., 2010), so that this might prevent growth of bacteria synthesising the branched GDGTs. Moreover, euxenia is less conducive to the degradation of organic matter (Canfield et al., 2005), and anoxic conditions were found to lead to enhanced preservation of (chemically similar) archaeal GDGTs (Sinninghe Damsté et al., 2002; Schouten et al., 2004; Huguet et al., 2009). If relevant, a sulfide-dependent biogeochemcial control on in situ production and/or decomposition of bacterial GDGTs would have been active throughout the Holocene, as we were able to extract pigments derived from anoxygenic phototrophs in all sediment samples (Wirth et al., 2012). In addition to its peculiar biogeochemistry, Lake Cadagno is characterised by a relatively small surface area, so that the flux of allochthonous organic matter to the sediments probably exceeds, and thus overprints, autochthonous production. This seems to be confirmed by the consistently high BIT values throughout the sedimentary sequence (Table A1 in the Appendix).

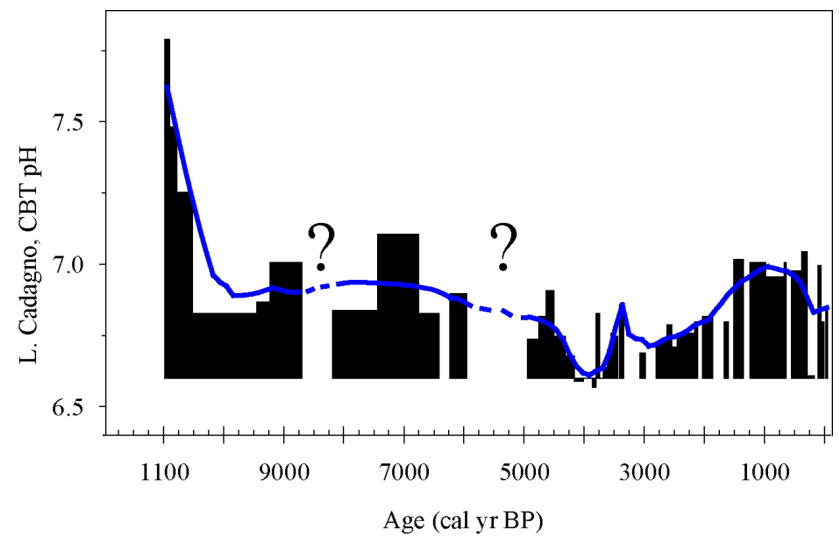

Fig. 6. Paleosoil pH estimates based on $\mathrm{CBT}$ ratios in the sediments of Lake Cadagno. Bars represent raw data (temporal resolution is indicated by the bar width) and the blue curve a low-pass filter (bisquare, 0.15). The dashed line section indicates gaps between the three separate core sections. The CBT-based estimate indicates a decrease of about $1 \mathrm{pH}$ unit during the early Holocene (ca. 11-10 cal kyr BP).

Soil from two sampling locations (Sites 4 and 8, Fig. 1) yielded CBT/MBT ratios that appeared "irregular" in that they translated into unrealistic (i.e. too high) MAAT values. We were not able to find these signatures anywhere in the sedimentary record, so that we suggest that the "irregular" soils are not common in the Lake Cadagno catchment. Further investigations are, however, needed to assign particular soil properties/conditions to such "irregular" GDGT signals, and we do not know whether similar features may have been responsible for erratic MAAT estimates in other catchments in previous studies. If abundant, such "irregular" soils clearly have the potential to influence MAAT estimates. As for Lake Cadagno, the admixture of GDGTs from these soils seems to be of minor importance, and provided the evidence discussed above, we conclude that its sediments represent an excellent archive to be used for MBT/CBT-paleothermometry.

\subsection{MBT/CBT-based MAAT estimates and comparison to instrumental data and independent proxy records}

For Lake Cadagno, we could show that branched GDGTs of soil origin are transferred by erosion to the sediment record where the primary GDGT signatures remain preserved, probably without substantial alteration by in situ GDGT production and/or early diagenesis. Therefore, it seems appropriate to calculate MAAT values using the global soil calibration (Weijers et al., 2007a). According to Eqs. (1)-(4), the composition of branched GDGTs in the lake sediment translates into paleo MAAT estimates, as depicted in Fig. 4a and e. The MAAT record indicates that temperature variations over the Holocene epoch were relatively subtle, with minima and maxima of about -1.4 and $1.7^{\circ} \mathrm{C}$, respectively 
(average $=-0.1{ }^{\circ} \mathrm{C} \pm 0.7 S_{\mathrm{D}}$ ), which, considering the modern MAAT of $\sim 0.5^{\circ} \mathrm{C}$ (SwissMeteo), appear reasonable. However, while we have provided circumstantial evidence that the environmental conditions in Lake Cadagno and its catchment are such that the soil-derived GDGT signal is well-preserved in the sedimentary matrix, further validation of our GDGT record is necessary to estimate its suitability for paleoclimate reconstructions, particularly with respect to the absolute magnitude of $T$ fluctuations. "Ground truthing" a novel paleoclimate proxy using realistic instrumental data is of paramount importance for assessing the quality of proxybased climate records. Yet, for our record, such calibration efforts are hampered by the fact that instrumental data (MeteoSwiss) are only available for the last $\sim 150 \mathrm{yr}$. Also, the relatively low temporal resolution of our proxy record prevents an in-depth comparison of measured versus proxy data. Thus, for the most part of our data set, we used an alternative, less direct approach for "ground truthing" by comparing our estimates to other independent proxy records.

\subsubsection{The late Holocene after 2 cal kyr BP}

The climate of the last 2 millennia received considerable scientific attention. Consequently, several proxy-based climate reconstructions ranging from regional to hemisphericalscales are available in literature and, in general, consensus exists with respect to magnitude and amplitude of major climate shifts. The MBT/CBT ratio from the youngest sediment slab translates into a MAAT value of $1.5^{\circ} \mathrm{C}$ for the Lake Cadagno region for the time period $\sim 1978$-present. This value is similar to the extrapolated instrumental average of $1.3^{\circ} \mathrm{C}$ (MeteoSwiss) for the Lake Cadagno region for the same time period. Absolute $T$ values are often compared to a long-term average, which typically represents the time period 1961-1990 (IPCC, 2007). During the second half of the 20th century, increasing deviations from this average $\left(\sim 0.5^{\circ} \mathrm{C}\right)$ were found, culminating in an extrapolated absolute MAAT value of $2.5^{\circ} \mathrm{C}$ for the Lake Cadagno region in 2011 (MeteoSwiss). Our most recent $T$ estimate thus seems to include, and consequently reflects, the ongoing $T$ increase during the 20th century.

Prior to the 20th century, our GDGT data indicate a MAAT minimum (up to $1^{\circ} \mathrm{C}$ colder than during the reference period) at about $225 \mathrm{cal}$ yr BP (i.e. from $\sim 284$ to $166 \mathrm{cal}$ $\mathrm{yr}$ BP). This agrees in timing and amplitude with independent proxy records, for instance paleo $T$ reconstructions based on $\delta^{18} \mathrm{O}$ signatures of a stalagmite in the Spannangel Cave (Fig. 4f) (Mangini et al., 2005) and shifts in the community assemblage of chironomids in Lake Silvaplana (Fig. 4g). However, these records indicate an intermediate $T$ high around $450 \mathrm{cal} \mathrm{yr} \mathrm{BP}$, which is not apparent in our record, possibly due to our rather low sampling resolution. The observed cold event coincides with the Little Ice Age (LIA) (IPCC, 2007). The LIA was first described in the context of glacier fluctuations in Sierra Nevada, USA (Matthes,
1939) and appears to be a common climate anomaly in the Northern Hemisphere (Fig. 4h) (Moberg et al., 2005). Prior to the LIA, the MBT/CBT ratios suggest that the climate at Lake Cadagno was considerably warmer. In timing, this warm period matches the so-called Medieval Warm Period (MWP), sometimes also referred to as the Medieval Climate Anomaly, a major Northern Hemispherical climate oscillation (Mann et al., 2009). Our record, as well as the proxy data from Lake Silvaplana and the Spannangel Cave, indicates MWP temperatures similar to the present-day values (i.e. $\sim 0.5^{\circ} \mathrm{C}$ higher than during the reference period 1961-1990).

Our MAAT reconstructions agree well with instrumental data and independent proxy reconstructions, not only in relative terms, but also with regards to absolute values. Compared to instrumental data and proxy records for the last $2 \mathrm{kyr}$, our reconstructions provide a robust record of relative $T$ change with a precision $<1{ }^{\circ} \mathrm{C}$ and an accuracy for absolute $T$ values $<1^{\circ} \mathrm{C}$. The error of the global soil calibration of Weijers et al. (2007a) is about $\pm 5^{\circ} \mathrm{C}$, but this is a systematic error in the absolute temperature estimates, not to be confused with inter-record $T$ variations (see discussion in Supplementary Info of Tierney et al., 2010b). Possibly, the large calibration error is related to the fact that the global soil calibration comprises many different soil types from various climate regions (Weijers et al., 2007a). These variations are clearly much smaller in our sample set, which reflects a small region with a fairly constrained MAAT. It is reasonable to assume that the reliable application of the global soil calibration to other lake systems might require a local/regional calibration, even if limnological/preservational conditions are similar to those in Lake Cadagno.

The rather far-reaching geographical extension of proxy evidence for the MWP and LIA suggests that these climate anomalies are driven by larger-scale phenomena. The exact mechanisms/processes that lead to the observed $T$ fluctuations are still uncertain, but several factors such as meltwater flux into the North Atlantic, fluctuations of the thermohaline circulation, solar irradiance, and volcanic eruptions were identified as potentially important processes, modulating atmospheric $T$ during the Holocene (Wanner et al., 2011 and references therein). Recent studies suggest that volcanic eruptions may have triggered the LIA (Miller et al., 2012), whereas solar activity could have induced the MWP (Mann et al., 2009 and references therein). Typically, it seems that a combination of several factors led to the observed $T$ anomalies. In any case, both the MWP and the LIA were likely linked to shifting atmospheric circulation patterns, affecting mean annual surface temperatures on land (Lamb, 1965; Mann et al., 2009; Trouet et al., 2009; Graham et al., 2010). Notably, Trouet et al. (2009) found that the North Atlantic Oscillation (NAO) was strengthened through tropospheric dynamics during a La Niña-like climate state in the Pacific and Indian Oceans during the MWP, while the NAO weakened during the LIA (Fig. 4i). A positive North 
Atlantic Oscillation Index (NAOI) reflects a higher than average atmospheric pressure difference between the subtropical Atlantic and the polar low pressure regime (Barnston and Livezey, 1987) and is associated with strong Westerlies and enhanced heat and moisture transport towards the mid-latitudes of the Northern Hemisphere (Hurrell, 1995). As a result, the Western European climate, particularly during wintertime, becomes rather mild and humid (Nesje et al., 2001; Jones et al., 2003; Luterbacher et al., 2004).

\subsubsection{The middle and early Holocene prior to $2 \mathrm{kyr}$ BP}

Our MBT/CBT record (Fig. 4a) and recently published $T$ records from the north Alpine Lake Egelsee (LarocqueTobler et al., 2010b; Larocque-Tobler, 2010) (Fig. 4b) and sea surface temperature (SST) records from the sub-polar NE Atlantic (Thornalley et al., 2009) (Fig. 4c) show similar patterns, at least with respect to the rough timing and sequence of climate undulations back until 8 cal kyr BP. A fairly good match was also found with respect to other records (not show here), for instance from the Spannagel Cave (Mangini et al., 2007), the Sargasso Sea (Keigwin, 1996) and, to a lesser extent, from the Central Alps (Heiri et al., 2003). In concert, our and other records indicate periods of elevated temperature at $\sim 1,3,5,7,9$ and 11 cal kyr BP. Still, ambiguities remain between the different records. Our GDGT data, for instance, indicate a $T$ high at $\sim 5 \mathrm{cal} \mathrm{kyr} \mathrm{BP}$, which seems significantly less pronounced in the chironomid-based paleo $T$ reconstructions from Lake Egelsee (Fig. 4). Moreover, the 9 cal kyr BP warm event indicated by independent records, as well as the so-called $8.2 \mathrm{kyr}$ event, a brief cold spell of a few hundred years, which has been found in many proxy records (Alley and Ágústsdóttir, 2005, and references therein), are not reflected in our MBT/CBT-based MAAT reconstructions. The hiatus from $\sim 8.3$ to $\sim 8.7 \mathrm{cal}$ kyr BP could be responsible for the absence of this event in our record. However, at this point, we are unable to explain why the MBT/CBT-paleothermometer did not record the warm phase at 9 cal kyr BP. We also lack data for the time period between $\sim 5$ and 6 cal kyr BP (as well as for some shorter episodes $<275 \mathrm{yr}$; Fig. $4 \mathrm{a}$, e), so further investigations are required to determine MAAT variations during these time periods.

Our record indicates a longer-term warming trend between 9-5 cal kyr BP, in agreement with pollen-based $T$ reconstructions for Western Europe (Davis et al., 2003). We propose this trend to be linked to the so-called Holocene temperature optimum (HTO). In Europe, the HTO was a time period ( $\sim 8$ to 5 cal kyr BP) of relatively high summertime warmth, which was most pronounced in higher latitude regions and in Eastern Europe, and rather less palpable in Southern and Western Europe (Davis et al., 2003; Battarbee and Binney, 2008; Renssen et al., 2009). The corresponding positive $T$ anomaly in the chironomid records (reflecting July air temperatures) of Laroque-Tobler et al. (2010) (Fig. 4b) and
Heiri et al. (2003) is more pronounced than suggested by our GDGT record, most likely because the latter reflects annual mean $T$ rather than summertime $T$.

Similar to the MWP and the LIA, at least some of the warm phases detected in our record were probably of considerable geographical extension and not only restricted to Western Europe. For example, broader-scale implications of the temperature fluctuations recorded in the Cadagno core for the continental/hemispherical climate are tentatively suggested by the good match of our data (back until 8 cal kyr BP) with a record of winter precipitation in South-West Norway (Fig. 4d) (Nesje et al., 2001). Elevated winter precipitation in North-West Europe is linked to comparably mild temperatures and strong westerly winds, and is thus a qualitative indicator for the strength of the NAO (Nesje et al., 2000; Reichert et al., 2001; Imhof et al., 2012). Accordingly, the NAO was strong during the warm phases at about 1,3 , 5, 7 and 9 cal kyr BP. Together with the findings of a dominantly positive NAOI during the MWP (Trouet et al., 2009), this may underscore a generally strong and far-reaching influence of the NAO on Holocene $T$ variations beyond Western Europe. Just as for the MWP and LIA, it remains unclear what the forcing factors are that may have triggered shifts in the NAO, and thus have led to the observed $T$ anomalies. Among other factors (see above), long-term trends in solar irradiance, particularly the so-called Bond cycles (Bond et al., 2001), have been invoked to explain Holocene $T$ variations, but typically, solar activity could not fully account for the observed variations (Wanner and Büttikofer, 2008; Wanner et al., 2011 and references therein). We could also only find a moderate match between solar activity and our MAAT record. The MAAT lows at $\sim 0.5$ (LIA), 4,6 and $10 \mathrm{cal} \mathrm{kyr}$ BP in our record roughly fit in timing with Bond events 0,3 , 4 and 7. However, it is difficult to implicate the cold event at $\sim 2.5 \mathrm{kyr}$ BP with the relatively long-lasting Bond event $2(\sim 2.8$ cal kyr BP), strongly overlapping with the apparent warm phase at $\sim 3$ cal kyr BP in our record. Thus, we conclude that MAAT variations in our record are not fully explainable by variations in solar activity.

In spite of the overall temporal consistency of our and other proxy records, the extremes of the observed $T$ anomalies seem sometimes to be offset by a few centuries. The chironomid-based $T$ record (Fig. 4b), for instance, indicates a relatively warm period at $3.3 \mathrm{cal} \mathrm{kyr} \mathrm{BP}$, whereas our and the SST records for the NE Atlantic (Fig. 4c) indicate that this event occurred slightly earlier. We attribute these apparent temporal offsets to inaccuracies of the applied age-depth models and to the soil origin of our GDGT record. The $2 \sigma$ range of our age model is on average $\pm 130 \mathrm{yr}$ (Table 2), while for the North Atlantic record it is $\pm 50 \mathrm{yr}$ (Thornalley et al., 2009). The $95 \%$ confidence interval for the Lake Egelsee record is $\pm 200 \mathrm{yr}$ (LarocqueTobler et al., 2010). Furthermore, the temporal resolution of our record is relatively low and variable. Depending on the source of the sediments (background sediments versus 
flood events), sampled sediment horizons can reflect time periods from decades to several centuries. Secondly, bioturbation as well as erosion/re-deposition processes in the lake's catchment probably led to mixing of material from different soil (and thus age) horizons. Obviously, the time period that is archived in GDGTs from a single soil horizon is a function of GDGT accumulation and erosion rates, parameters that were not assessed for the Lake Cadagno Region. At a depth of a few decimetres only, organic carbon in Alpine soils may already be several hundred years old (Conen et al., 2008). It thus seems likely that mixing of GDGTs from deeper horizons with top soil (i.e. recently produced) material could have had a significant effect. We therefore speculate that the organic matter (including the relevant GDGTs) of top soils, which is transported into the lake, comprises a relatively broad age spectrum that "blurs" the lower and upper age limit of a given sediment sample thus biasing the temporal resolution of our records.

While our and several other independent paleo $T$ reconstructions suggest relative warm/cold climate episodes that are temporally spaced by $\sim 2 \mathrm{kyr}$ (see above), it should be noted that comparably little consensus exists on paleo- $T$ undulations during the early to mid Holocene - in contrast to the late Holocene (Wanner et al., 2011 and references therein). Proxy records of the earlier Holocene indicate a very high spatio-temporal variability (Wanner et al., 2011). We can only speculate as to what the reasons for the observed variability of paleo- $T$ proxies are. In parts, this may be related to (true) regional differences, dating uncertainties and/or temporal differences of the captured $T$ signal (e.g. MAAT versus summertime $T$ ), as discussed above. In addition, factors other than $T$ may have affected some proxy records. For instance, population dynamics can strongly bias $T$ reconstructions that are based on species compositions (e.g. Laroque-Tobler, 2010), glacier advance/shrinkage is modulated by a complex combination of $T$ and precipitation (e.g. Nesje, 2008; Steiner et al., 2008; Imhof et al., 2012), just as dendroclimatological records are not only influenced by $T$, but also by precipitation (e.g. Nicolussi et al., 2009; Linderholm et al., 2010 and references therein). Together, these observations emphasize the need for additional continental paleoclimate reconstructions, particularly for the early to mid Holocene, and an in-depth understanding of the factors that influence the respective proxy indicators.

\subsection{Paleo soil pH}

Our CBT-based pH estimates of soil $\mathrm{pH}$ (including the "irregular" soils) compare well with the instrumentally measured $\mathrm{pH}$ (Fig. 5). Also, the $\mathrm{pH}$ estimate from the surface sediment sample ( $\mathrm{pH}=6.9)$ agrees with the average CBT-based soil $\mathrm{pH}$ estimates (average $\mathrm{pH}=6.8$ ). This again indicates a dominant soil origin for the sedimentary branched GDGTs. At present, $\mathrm{pH}$ is $\sim 8.5$ in the surface waters, decreasing through the chemocline to about 7.2 in the monimolimnion. Water column $\mathrm{pH}$ is thus generally higher than soil $\mathrm{pH}$ from the watershed of the lake. As Lake Cadagno is recharged with carbonate-rich water from sub-aquatic springs (Del Don et al., 2001), the $\mathrm{pH}$ of the lake (bottom) water is well-buffered, and it appears unlikely that the buffering capacity of the lake has changed over the last millennia. As a consequence, we assume that changes in sedimentary CBT ratios are due to changes in the $\mathrm{pH}$ of the catchment soils and not in the lake water column.

The most prominent feature of the soil $\mathrm{pH}$ record is a decrease from $\mathrm{pH} 7.8$ to 6.8 in the very early Holocene (11-10 cal kyr BP; Fig. 6). During the subsequent time period until present, soil $\mathrm{pH}$ did not deviate strongly from its long-term average of $\mathrm{pH} 6.9$, with the exception of an apparent $\mathrm{pH}$ minimum ( $\mathrm{pH}=6.6)$ during the Bronze Age $(\sim 4 \mathrm{cal} \mathrm{kyr} \mathrm{BP})$ and a subsequent $\mathrm{pH}$ increase that peaked with a $\mathrm{pH}$ value of 7.0 at $1 \mathrm{cal} \mathrm{kyr} \mathrm{BP}$. A similar $\mathrm{pH}$ decrease of about $0.5 \mathrm{pH}$ units (at $\sim 12$ to $10 \mathrm{cal} \mathrm{kyr} \mathrm{BP}$ ) has been reported from a sediment record from Central Africa (Weijers et al., 2007b), and it was attributed to enhanced precipitation at the end of the Younger Dryas. Indeed, strong precipitation events may cause leaching of basic ions, which in turn leads to soil acidification (Schaetzl and Anderson, 2005). However, lake-level reconstructions from the Jura Mountains indicate only a moderately humid climate during the early Holocene in Western Europe (Magny, 2004). We therefore suggest that the drop in soil $\mathrm{pH}$ at $11-10 \mathrm{cal} \mathrm{kyr} \mathrm{BP}$ in the Lake Cadagno region is the result of a combination of climate humidity and the primary development and evolution of soils and vegetation after the retreat of the glacier (rather than precipitation alone). Soils in the Lake Cadagno region prior $10 \mathrm{cal}$ kyr BP were in a very early development stage, in which the soil buffering capacity was typically determined by a fast-leaching carbonate buffer (Schaetzl and Anderson, 2005; Jenny, 2011). Also, the development of vegetation leading to a build-up of organic material, and thus organic acids, during soil maturation likely lowered soil pH (Jenny, 2011 and references therein). However, the second $\mathrm{pH}$ decrease ( 4 cal kyr BP) likely implies an increase in precipitation during the Bronze Age. Mature soils are primarily buffered by silicates, which are more resistant to acidification. Hence, an elevated buffering capacity of more matured soil in the Cadagno catchment would probably have prevented further acidification related to soil maturation alone. Enhanced precipitation during the Bronze Age is confirmed by flood frequency reconstructions for Lake Cadagno (Wirth et al., 2011), and is qualitatively consistent with low $\delta^{18} \mathrm{O}$ values from the Spannagel Cave record (Mangini et al., 2007). The apparently variable response of paleo soil $\mathrm{pH}$ in the Lake Cadagno catchment provides evidence that this proxy is qualitative rather than quantitative, and affected by a combination of several parameters, including not only precipitation, but also the geological and biological setting, at least in high Alpine regions. 


\section{Conclusions}

We recovered an almost continuous Holocene sediment sequence from the meromictic Swiss Lake Cadagno in a high Alpine setting, providing a well-preserved archive for paleoclimate reconstructions. We could show that soil-derived, branched GDGTs are transferred and preserved in the sedimentary matrix, and early diagenesis and/or dilution by in situ production of branched GDGTs are apparently not important at Lake Cadagno. Both processes can ultimately affect the GDGT composition in the sediment and thus lead to biased MBT/CBT-based paleotemperature estimates. We putatively attribute the absence of these biasing effects to the euxinic/sulfidic conditions of bottom waters, preventing biosynthesis and/or decomposition of the relevant GDGTs. Also, the high import of soil-derived GDGTs is likely to overprint any in situ signature (if present at all). Our MBT/CBT-based record agrees well with instrumental data, as well as with various other independent proxybased paleoclimate reconstructions. We therefore argue that the application of the MBT/CBT-paleothermometer to Lake Cadagno sediments provides a robust and quantitative measure for paleo MAAT and soil $\mathrm{pH}$ variations during the Holocene. The reconstructed temperature variations together with other proxy records indicate a broad geographical extension of surface temperature maxima in Europe that seem temporally spaced by $\sim 2000 \mathrm{yr}$ and are linked to the North Atlantic Oscillation. Our data set indicates that the Holocene was characterised by subtle but resolvable temperature variations of a few ${ }^{\circ} \mathrm{C}$ in Central Europe and the Alpine realm. Our GDGT record also suggests that putative links between climate humidity and soil $\mathrm{pH}$ are not linear. We argue that observed paleosoil $\mathrm{pH}$ variations during the Holocene in the Lake Cadagno catchment were probably controlled by multiple factors, including climate, humidity as well as soil development with changing buffering capacities with ongoing soil maturation. The applicability of the MBT/CBT-paleothermometer to lakes with preservation conditions and sedimentation regimes other than those found in Lake Cadagno needs further testing, particularly with respect to environmental factors that control the in situ production or decomposition of bacterial GDGTs in the water column and/or sediments. Moreover, soils provide timeintegrated geochemical signals, so that the time scale captured by the GDGT proxy is, to some extent, uncertain, and possibly markedly different from the time of sedimentation. This may complicate the temporal resolution and direct comparison to other paleo-proxies. Nevertheless, despite these constraints, it is encouraging with regards to future applications of GDGT measurements in paleoclimatological studies that the MBT/CBT-paleothermometer has the potential to resolve very subtle temperature changes, at least in lakes with specific environmental/preservational conditions.
Appendix

Ia

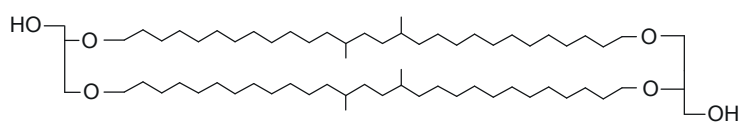

$\mathrm{Ib}$

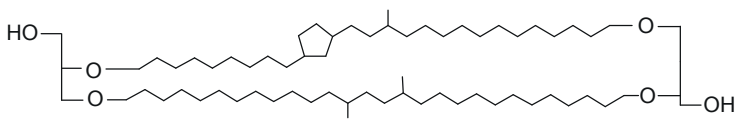

Ic

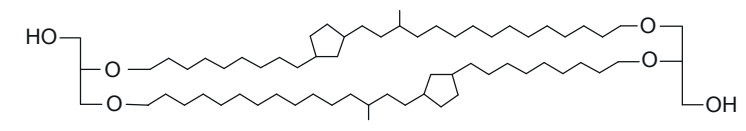

IIa

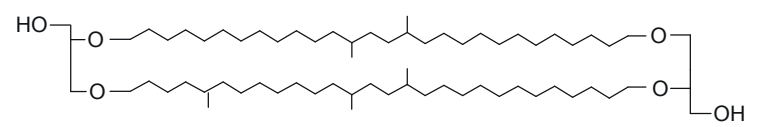

$\mathrm{IIb}$

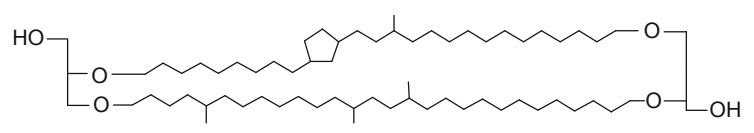

IIc

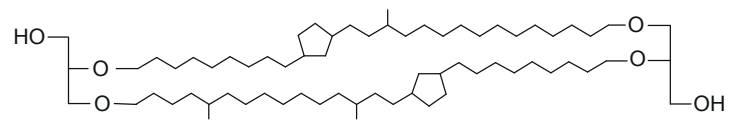

IIIa

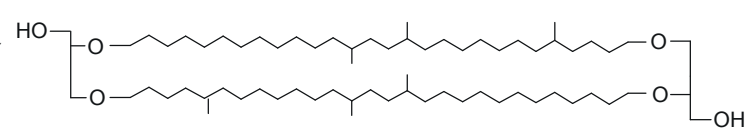

IIIb

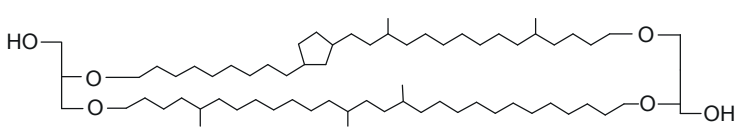

IIIc

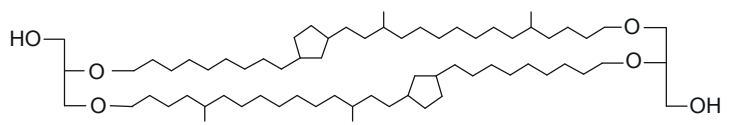

IV

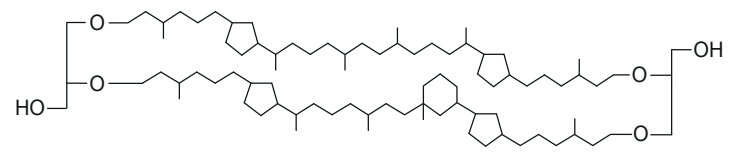

Fig. A1. Chemical structure of bacterial glycerol dialkyl glycerol tetraethers (GDGTs; Ia-IIIc) and crenarchaeol (IV) comprised in the MBT/CBT-paleothermometer and BIT ratio. 
Table A1. MBT, CBT and BIT values from Lake Cadagno sediment samples.

\begin{tabular}{|c|c|c|c|c|c|c|}
\hline Sample ID & MBT & CBT & BIT & $\begin{array}{r}\text { Age start of sample } \\
\text { (cal yr BP) }\end{array}$ & $\begin{array}{r}\text { Age end of sample } \\
(\text { cal yr BP) }\end{array}$ & $\begin{array}{r}\text { Composite sediment depth } \\
(\mathrm{w} / \mathrm{o} \mathrm{MM}, \mathrm{cm})\end{array}$ \\
\hline $\mathrm{SC}-1$ & 0.29 & 0.73 & 0.99 & -59 & -28 & 2.5 \\
\hline $\mathrm{SC}-2$ & \multicolumn{3}{|c|}{ inadequate chromatography } & -28 & 4 & 7.5 \\
\hline $\mathrm{SC}-3$ & 0.26 & 0.74 & 0.98 & 4 & 54 & 12.5 \\
\hline $\mathrm{SC}-4$ & 0.23 & 0.67 & 0.95 & 54 & 104 & 17.5 \\
\hline SC-14 & 0.26 & 0.82 & 0.98 & 166 & 284 & 27.0 \\
\hline $\mathrm{SC}-15$ & 0.23 & 0.65 & 0.98 & 284 & 376 & 32.0 \\
\hline SC-16 & 0.26 & 0.68 & 0.98 & 376 & 548 & 37.0 \\
\hline SC-18 & 0.26 & 0.67 & 0.98 & 548 & 635 & 42.0 \\
\hline A1-6 & 0.27 & 0.68 & 0.98 & 666 & 977 & 47.0 \\
\hline A1-7 & 0.27 & 0.67 & 0.98 & 977 & 1240 & 57.0 \\
\hline A1-9 & \multicolumn{3}{|c|}{ inadequate chromatography } & 1249 & 1347 & 68.5 \\
\hline A2-1 & 0.28 & 0.66 & 0.98 & 1351 & 1507 & 79.5 \\
\hline A2-6 & 0.27 & 0.74 & 0.98 & 1597 & 1664 & 89.5 \\
\hline A2-7 & \multicolumn{3}{|c|}{ inadequate chromatography } & 1664 & 1860 & 97.0 \\
\hline A2-8 & 0.27 & 0.74 & 0.98 & 1860 & 2032 & 107.0 \\
\hline A3-1 & 0.24 & 0.75 & 0.98 & 2110 & 2160 & 111.5 \\
\hline A3-3 & 0.25 & 0.76 & 0.98 & 2160 & 2366 & 118.0 \\
\hline A3-4 & 0.25 & 0.76 & 0.98 & 2366 & 2451 & 128.0 \\
\hline A3-5 & 0.25 & 0.78 & 0.98 & 2451 & 2535 & 138.0 \\
\hline A3-6 & 0.26 & 0.75 & 0.98 & 2535 & 2619 & 148.0 \\
\hline A3-7 & 0.27 & 0.77 & 0.97 & 2619 & 2703 & 158.0 \\
\hline A3-8 & 0.26 & 0.77 & 0.98 & 2703 & 2797 & 168.0 \\
\hline A3-9 & \multicolumn{3}{|c|}{ inadequate chromatography } & 2797 & 2974 & 178.0 \\
\hline \multirow[t]{2}{*}{ A3-10 } & 0.27 & 0.79 & 1.00 & 2974 & 3070 & 188.0 \\
\hline & \multicolumn{3}{|c|}{ discontinuous composite } & & & \\
\hline B1-1 & 0.26 & 0.72 & 0.97 & 3343 & 3409 & 226.5 \\
\hline B1-5 & 0.26 & 0.76 & 0.98 & 3438 & 3532 & 237.0 \\
\hline B1-6 & 0.26 & 0.76 & 0.97 & 3532 & 3552 & 247.0 \\
\hline B1-7 & 0.27 & 0.79 & 0.97 & 3552 & 3613 & 257.0 \\
\hline B1-8 & 0.27 & 0.81 & 0.97 & 3613 & 3684 & 268.0 \\
\hline B2-1 & 0.26 & 0.88 & 0.98 & 3684 & 3743 & 279.0 \\
\hline B2-2 & 0.25 & 0.73 & 0.96 & 3743 & 3802 & 289.0 \\
\hline B2-3 & 0.29 & 0.83 & 0.97 & 3802 & 3861 & 299.0 \\
\hline B2-4 & 0.26 & 0.82 & 0.98 & 3861 & 3941 & 309.0 \\
\hline B3-5 & 0.26 & 0.83 & 0.98 & 4010 & 4162 & 326.5 \\
\hline B3-6 & 0.26 & 0.79 & 0.98 & 4162 & 4312 & 336.5 \\
\hline B3-7 & 0.26 & 0.77 & 0.98 & 4312 & 4497 & 346.5 \\
\hline B3-8 & 0.26 & 0.70 & 0.97 & 4497 & 4630 & 356.5 \\
\hline B3-9 & 0.26 & 0.74 & 0.98 & 4630 & 4746 & 359.5 \\
\hline \multirow[t]{2}{*}{ B3-10 } & 0.27 & 0.77 & 0.98 & 4746 & 4942 & 369.5 \\
\hline & \multicolumn{3}{|c|}{ discontinuous composite } & & & \\
\hline $\mathrm{C} 1-8$ & 0.25 & 0.71 & 0.98 & 5953 & 6231 & 411.5 \\
\hline $\mathrm{C} 2-3$ & 0.26 & 0.74 & 0.98 & 6412 & 6754 & 422.5 \\
\hline C2-4 & 0.27 & 0.74 & 0.98 & 6754 & 7439 & 432.5 \\
\hline C2-5 & 0.26 & 0.73 & 0.98 & 7439 & 8188 & 442.5 \\
\hline C3-2 & 0.24 & 0.67 & 0.97 & 8699 & 9225 & 455.5 \\
\hline C3-3 & 0.24 & 0.72 & 0.97 & 9225 & 9444 & 459.5 \\
\hline C3-4 & 0.25 & 0.74 & 0.97 & 9444 & 9755 & 467.0 \\
\hline C3-5 & 0.24 & 0.73 & 0.95 & 9755 & 10514 & 473.0 \\
\hline C3-6 & 0.23 & 0.57 & 0.82 & 10514 & 10625 & 479.5 \\
\hline C3-7 & 0.23 & 0.57 & 0.84 & 10625 & 10774 & 487.5 \\
\hline C3-8 & 0.22 & 0.48 & 0.88 & 10774 & 10903 & 497.5 \\
\hline C3-9 & 0.18 & 0.37 & 0.77 & 10903 & 10981 & 507.5 \\
\hline
\end{tabular}


Table A2. MBT-,CBT and BIT-values from soil samples collected in the Lake Cadagno catchment.

\begin{tabular}{rrrrrr}
\hline $\begin{array}{r}\text { Sampling } \\
\text { pos. }\end{array}$ & $\begin{array}{r}\text { Sample } \\
\text { ID }\end{array}$ & MBT & CBT & BIT & $\begin{array}{r}\text { Soil depth } \\
(\mathrm{cm})\end{array}$ \\
\hline 2 & LC-S1 & 0.27 & 0.75 & 0.98 & surface \\
3 & LC-S2 & 0.34 & 1.41 & 1.00 & 7.5 \\
& LC-S3 & 0.34 & 1.12 & 1.00 & 22.5 \\
& LC-S4 & 0.34 & 1.19 & 0.99 & 37.5 \\
& LC-S5 & 0.39 & 1.23 & 0.97 & 52.5 \\
4 & LC-S10 & 0.25 & 0.66 & 0.96 & surface \\
6 & LC-S18 & 0.32 & 1.22 & 0.99 & surface \\
7 & LC-S19 & 0.31 & 0.83 & 1.00 & surface \\
9 & LC-S22 & 0.18 & 0.28 & 1.00 & 7.5 \\
& LC-S23 & & & & 22.5 \\
& LC-S24 & 0.19 & 0.36 & 0.99 & 37.5 \\
4 & LC-S6 & 0.50 & 0.80 & 1.00 & 7.5 \\
& LC-S7 & 0.54 & 1.40 & 1.00 & 22.5 \\
& LC-S8 & 0.61 & 1.15 & 0.98 & 37.5 \\
& LC-S9 & 0.66 & 1.36 & 0.98 & 52.5 \\
8 & LC-S20 & 0.42 & 1.19 & 1.00 & 7.5 \\
& LC-S21 & 0.49 & 1.27 & 0.99 & 22.5 \\
\hline
\end{tabular}

Acknowledgements. The authors thank M. Bonalumi, L. Glur, R. Hofmann and U. van Raden for assistance during sediment coring. N. Sax and M. Rollog are thanked for their assistance during sampling, and M. Baas and H. Hürlimann for support in the laboratory. We are grateful to R. Peduzzi, S. Peduzzi and M. Tonolla from the foundation "Centro Biologia Alpina" who made this research on Lake Cadagno possible and helped with the logistics. We are particularly grateful to I. Larocque-Tobler for providing raw data of $T$ estimates for the Lake Egelsee region as well as to MeteoSwiss for providing instrumental climate data and Swisstopo for geographical data. We also thank F. Conen and M. Elvert for commenting an early version of this manuscript. This work was supported by the Swiss National Science Foundation project grants 200021-121909 and IZK0Z2-131407. The research leading to these results has received funding from the European Research Council under the European Union's Seventh Framework Programme (FP7/2007-2013)/ERC grant agreement no. [226600].

Edited by: M. Fuchs

\section{References}

Alley, R. B. and Ágústsdóttir, A. M.: The 8k event: cause and consequences of a major Holocene abrupt climate change, Quaternary Sci. Rev., 24, 1123-1149, 2005.

Barnston, A. G. and Livezey, R. E.: Classification, seasonality and persistence of low-frequency atmospheric circulation patterns, Mon. Weather Rev., 115, 1083-1126, 1987.

Battarbee, R. W. and Binney, H. A.: Natural Climate Variability and Global Warming: A Holocene Perspective, Wiley-Blackwell, 2008.
Bechtel, A., Smittenberg, R. H., Bernasconi, S. M., and Schubert, C. J.: Distribution of branched and isoprenoid tetraether lipids in an oligotrophic and a eutrophic Swiss lake: Insights into sources and GDGT-based proxies, Org. Geochem., 41, 822-832, 2010.

Blaauw, M: Methods and code for "classical" age-modelling of radiocarbon sequences, Quat. Geochronol., 5, 512-518, 2010

Blaga, C. I., Reichart, G.-J., Heiri, O., and Sinninghe Damsté, J. S.: Tetraether membrane lipid distributions in water-column particulate matter and sediments: a study of 47 European lakes along a north-south transect, J. Paleolimnol., 41, 523-540, 2009.

Blaga, C. I., Reichart, G.-J., Schouten, S., Lotter, A. F., Werne, J. P., Kosten, S., Mazzeo, N., Lacerot, G., and Sinninghe Damsté, J. S.: Branched glycerol dialkyl glycerol tetraethers in lake sediments: Can they be used as temperature and $\mathrm{pH}$ proxies?, Org. Geochem., 41, 1225-1234, 2010.

Bond, G., Kromer, B., Beer, J., Muscheler, R., Evans, M. N., Showers, W., Hoffmann, S., Lotti-Bond, R., Hajdas, I., and Bonani, G.: Persistent Solar Influence on North Atlantic Climate During the Holocene, Science, 294, 2130-2136, 2001.

Brassell, S. C., Eglinton, G., Marlowe, I. T., Pflaumann, U., and Sarnthein, M.: Molecular stratigraphy: a new tool for climatic assessment, Nature, 320, 129-133, 1986.

Bronk Ramsey, C.: Bayesian Analysis of Radiocarbon Dates, Radiocarbon, 51, 337-360, 2009.

Canfield, D. E., Kristensen, E., and Thamdrup, B.: Aquatic Geomicrobiology, Elsevier, 2005.

Castañeda, I. S. and Schouten, S.: A review of molecular organic proxies for examining modern and ancient lacustrine environments, Quaternary Sci. Rev., 30, 2851-2891, 2011.

Conen, F., Zimmermann, M., Leifeld, J., Seth, B., and Alewell, C.: Relative stability of soil carbon revealed by shifts in $\delta^{51} \mathrm{~N}$ and C:N ratio, Biogeosciences, 5, 123-128, doi:10.5194/bg-5-1232008, 2008.

Davis, B. A. S., Brewer, S., Stevenson, A. C., Guiot, J., and Data, C.: The temperature of Europe during the Holocene reconstructed from pollen data, Quaternary Sci. Rev., 22, 1701-1716, 2003.

Deevey, E. S., Gross, M. S., Hutchinson, G. E., and Kraybill, H. L.: The natural C14 contents of materials from hard-water lakes, P. Natl. Aacad. Sci. USA, 40, 285-288, 1954.

Del Don, C., Hanselmann, K. W., Peduzzi, R., and Bachofen, R.: The meromictic alpine Lake Cadagno: Orographical and biogeochemical description, Aquat. Sci., 63, 70-90, 2001.

Fawcett, P. J., Werne, J. P., Anderson, R. S., Heikoop, J. M., Brown, E. T., Berke, M. A., Smith, S. J., Goff, F., Donohoo-Hurley, L., Cisneros-Dozal, L. M., Schouten, S., Sinninghe Damste, J. S., Huang, Y., Toney, J., Fessenden, J., WoldeGabriel, G., Atudorei, V., Geissman, J. W., and Allen, C. D. : Extended megadroughts in the southwestern United States during Pleistocene interglacials, Nature, 470, 518-521, 2011.

Graham, N., Ammann, C., Fleitmann, D., Cobb, K., and Luterbacher, J.: Support for global climate reorganization during the "Medieval Climate Anomaly", Clim. Dynam., 37, 1217-1245, 2010.

Hanselmann, K. W. and Hutter, R.: Geomicrobiological coupling of sulfur and iron cycling in anoxic sediments of a meromictic lake: sulfate reduction and sulfide sources and sinks in Lake Cadagno, Documenta Ist. ital. Idrobiol., 63, 85-98, 1998. 
Hazel, J. R. and Eugene Williams, E.: The role of alterations in membrane lipid composition in enabling physiological adaptation of organisms to their physical environment, Prog. Lipid Res., 29, 167-227, 1990.

Heiri, O., Lotter, A. F., Hausmann, S., and Kienast, F.: A chironomid-based Holocene summer air temperature reconstruction from the Swiss Alps, Holocene, 13, 477-484, 2003.

Heiri, O., Tinner, W., and Lotter, A. F.: Evidence for cooler European summers during periods of changing meltwater flux to the North Atlantic, P. Natl. Aacad. Sci. USA, 101, 15285-15288, 2004.

Hoefs, M. J. L., Versteegh, G. J. M., Rijpstra, W. I. C., de Leeuw, J. W., and Damste, J. S. S.: Postdepositional oxic degradation of alkenones: Implications for the measurement of palaeo sea surface temperatures, Paleoceanography, 13, 42-49, 1998.

Hopmans, E. C., Weijers, J. W. H., Schefuss, E., Herfort, L., Sinninghe Damsté, J. S., and Schouten, S.: A novel proxy for terrestrial organic matter in sediments based on branched and isoprenoid tetraether lipids, Earth Planet. Sci. Lett., 224, 107-116, 2004.

Huguet, C., Hopmans, E. C., Febo-Ayala, W., Thompson, D. H., Sinninghe Damsté, J. S., and Schouten, S.: An improved method to determine the absolute abundance of glycerol dibiphytanyl glycerol tetraether lipids, Org. Geochem., 37, 1036-1041, 2006.

Huguet, C., Kim, J. H., de Lange, G. J., Sinninghe Damsté, J. S, and Schouten, S.: Effects of long term oxic degradation on the $\mathrm{U}_{37}^{K^{\prime}}$, TEX $_{86}$ and BIT organic proxies, Org. Geochem., 40, 1188-1194, 2009.

Hurrell, J. W.: Decadal Trends in the North Atlantic Oscillation: Regional Temperatures and Precipitation, Science, 269, 676679, 1995.

Imhof, P., Nesje, A., and Nussbaumer, S. U. : Climate and glacier fluctuations at Jostedalsbreen and Folgefonna, southwestern Norway and in the western Alps from the 'Little Ice Age' until the present: The influence of the North Atlantic Oscillation, Holocene, 22, 235-247, 2012.

IPCC: Climate Change 2007 - The Physical Science Basis - Contribution of Working Group I to the Fourth Assessment Report of the Intergovernmental Panel on Climate Change, edited by: Solomon, S., Qin, D., Manning, M., Marquis, M., Averyt, K., Tignor, M. M. B., and LeRoy Miller, H. J., Cambridge University Press, 2007.

Jenny, H.: Factors of Soil Formation: A System of Quantitative Pedology, Dover Publications, 2011.

Jones, P. D., Osborn, T. J., and Briffa, K. R.: Pressure-Based Measures of the North Atlantic Oscillation (NAO): A Comparison and an Assessment of Changes in the Strength of the NAO and in Its Influence on Surface Climate Parameters, in: The North Atlantic Oscillation - Climatic Significance and Environmental Impact, edited by: Hurrel, J. W., Kushnir, Y., Ottersen, G., and Visbeck, M., American Geophysical Union, Washington DC, 51-63, 2003.

Keigwin, L. D.: The Little Ice Age and Medieval Warm Period in the Sargasso Sea, Science, 274, 1503-1508, 1996.

Lamb, H. H.: The early medieval warm epoch and its sequel, Palaeogeogr. Palaeocl., 1, 13-37, 1965.

Larocque-Tobler, I.: Reconstructing temperature at Egelsee, Switzerland, using North American and Swedish chironomid transfer functions: potential and pitfalls, J. Paleolimnol., 44,
243-251, 2010.

Larocque-Tobler, I., Grosjean, M., Heiri, O., and Trachsel, M.: High-resolution chironomidinferred temperature history since AD 1580 from varved Lake Silvaplana, Switzerland: comparison with local and regional reconstructions, Holocene, 19, 12011212, 2009.

Larocque-Tobler, I., Grosjean, M., Heiri, O., Trachsel, M., and Kamenik, C.: Thousand years of climate change reconstructed from chironomid subfossils preserved in varved lake Silvaplana, Engadine, Switzerland, Quaternary Sci. Rev., 29, 1940-1949, 2010 a.

Larocque-Tobler, I., Heiri, O., and Wehrli, M.: Late Glacial and Holocene temperature changes at Egelsee, Switzerland, reconstructed using subfossil chironomids, J. Paleolimnol., 43, 649666, 2010b.

Leng, M. J. and Marshall, J. D.: Palaeoclimate interpretation of stable isotope data from lake sediment archives, Quaternary Sci. Rev., 23, 811-831, 2004.

Linderholm, H. W., Björklund, J. A., Seftigen, K., Gunnarson, B. E., Grudd, H., Jeong, J.-H., Drobyshev, I., and Liu, Y.: Dendroclimatology in Fennoscandia - from past accomplishments to future potential, Clim. Past, 6, 93-114, doi:10.5194/cp-6-93-2010, 2010.

Loomis, S. E., Russell, J. M., and Sinninghe Damsté, J. S.: Distributions of branched GDGTs in soils and lake sediments from western Uganda: Implications for a lacustrine paleothermometer, Org. Geochem., 42, 739-751, 2011.

Luterbacher, J., Dietrich, D., Xoplaki, E., Grosjean, M., and Wanner, H.: European Seasonal and Annual Temperature Variability, Trends, and Extremes Since 1500, Science, 303, 1499-1503, 2004.

Magny, M.: Holocene climate variability as reflected by midEuropean lake-level fluctuations and its probable impact on prehistoric human settlements, Quat. Int., 113, 65-79, 2004.

Mangini, A., Spotl, C., and Verdes, P.: Reconstruction of temperature in the Central Alps during the past $2000 \mathrm{yr}$ from a $\delta^{18} \mathrm{O}$ stalagmite record, Earth Planet. Sci. Lett., 235, 741-751, 2005.

Mangini, A., Verdes, P., Spötl, C., Scholz, D., Vollweiler, N., and Kromer, B.: Persistent influence of the North Atlantic hydrography on central European winter temperature during the last 9000 years, Geophys. Res. Lett., 34, L02704, doi:10.1029/2006GL028600, 2007.

Mann, M. E., Zhang, Z., Rutherford, S., Bradley, R. S., Hughes, M. K., Shindell, D., Ammann, C., Faluvegi, G., and Ni, F.: Global Signatures and Dynamical Origins of the Little Ice Age and Medieval Climate Anomaly, Science, 326, 1256-1260, 2009.

Matthes, F. E.: Report of the Committee on Glaciers, Trans. Am. Geophys. Union, 20, 518-535, 1939.

Miller, G. H., Geirsdóttir, Zhong, Y., Larsen, D. J., Otto-Bliesner, B. L., Holland, M. M., Bailey, D. A., Refsnider, K. A., Lehman, S. J., Southon, J. R., Anderson, C., Björnsson, H., and Thordarson, T.: Abrupt onset of the Little Ice Age triggered by volcanism and sustained by sea-ice/ocean feedbacks, Geophys. Res. Lett., 39, L02708-L02708, doi:10.1029/2011GL050168, 2012.

Moberg, A., Sonechkin, D. M., Holmgren, K., Datsenko, N. M., and Karlen, W.: Highly variable Northern Hemisphere temperatures reconstructed from low- and high-resolution proxy data, Nature, 433, 613-617, 2005. 
Nesje, A., Lie, O., and Dahl, S. O.: Is the North Atlantic Oscillation reflected in Scandinavian glacier mass balance records?, J. Quaternary Sci., 15, 587-601, 2000.

Nesje, A., Matthews, J. A., Dahl, S. O., Berrisford, M. S., and Andersson, C.: Holocene glacier fluctuations of Flatebreen and winter-precipitation changes in the Jostedalsbreen region, western Norvay, based on glaciolacustrine sediment records, Holocene, 11, 267-280, 2001.

Nicolussi, K., Kaufmann, M., Melvin, T. M., van der Plicht, J., Schießling, P., and Thurner, A. : A 9111 year long conifer treering chronology for the European Alps: a base for environmental and climatic investigations, Holocene, 19, 909-920, 2009.

Pearson, E. J., Juggins, S., Talbot, H. M., Weckstr “om, J., Ros'en, P., Ryves, D. B., Roberts, S. J., and Schmidt, R.: A lacustrine GDGT-temperature calibration from the Scandinavian Arctic to Antarctic: Renewed potential for the application of GDGTpaleothermometry in lakes, Geochim. Cosmochim. Acta, 75, 6225-6238, 2011.

Powers, L., Werne, J. P., Vanderwoude, A. J., Sinninghe Damsté, J. S., Hopmans, E. C., and Schouten, S.: Applicability and calibration of the TEX86 paleothermometer in lakes, Org. Geochem., 41, 404-413, 2010.

Reichert, B. K., Bengtsson, L., and Oerlemans, J.: Midlatitude forcing mechanisms for glacier mass balance investigated using general circulation models, J. Climate, 14, 3767-3784, 2001.

Reimer, P. J., Baillie, M. G. L., Bard, E., Bayliss, A., Beck, J. W., Blackwell, P. G., Ramsey, C. B., Buck, C. E., Burr, G. S., Edwards, R. L., Friedrich, M., Grootes, P. M., Guilderson, T. P., Hajdas, I., Heaton, T. J., Hogg, A. G., Hughen, K. A., Kaiser, K. F., Kromer, B., McCormac, F. G., Manning, S. W., Reimer, R. W., Richards, D. A., Southon, J. R., Talamo, S., Turney, C. S. M., van der Plicht, J., and Weyhenmeye, C. E.: intcal09 and marine09 radiocarbon age calibration curves, 0-50,000 years cal BP, Radiocarbon, 51, 1111-1150, 2009.

Renssen, H., Seppa, H., Heiri, O., Roche, D. M., Goosse, H., and Fichefet, T.: The spatial and temporal complexity of the Holocene thermal maximum, Nat. Geosci., 2, 410-413, 2009.

Schaetzl, R. and Anderson, S.: Soils: Genesis and Geomorphology, Cambridge University Press, 2005.

Schouten, S., Hopmans, E. C., Schefuss, E., and Damste, J. S. S.: Distributional variations in marine crenarchaeotal membrane lipids: a new tool for reconstructing ancient sea water temperatures?, Earth Planet. Sci. Lett., 204, 265-274, 2002.

Schouten, S., Hopmans, E. C., and Damste, J. S. S.: The effect of maturity and depositional redox conditions on archaeal tetraether lipid palaeothermometry, Org. Geochem., 35, 567-571, 2004.

Schouten, S., Huguet, C., Hopmans, E. C., Kienhuis, M. V. M., and Sinninghe Damsté, J. S.: Analytical methodology for TEX 86 paleothermometry by high-performance liquid chromatography/atmospheric pressure chemical ionization-mass spectrometry, Anal. Chem., 79, 2940-2944, 2007.

Schürmann, A., Mohn, J., and Bachofen, R.: $\mathrm{N}_{2} \mathrm{O}$ emissions from snow-covered soils in the Swiss Alps, Tellus Ser. B, 54, 134-142, 2002.

Seppä, H. and Bennett, K. D.: Quaternary pollen analysis: recent progress in palaeoecology and palaeoclimatology, Prog. Phys. Geog., 27, 548-579, 2003.
Sinninghe Damsté, J. S., Hopmans, E. C., Pancost, R. D., Schouten, S., and Geenevasen, J. A. J.: Newly discovered non-isoprenoid glycerol dialkyl glycerol tetraether lipids in sediments, Chem. Commun., 17, 1683-1684, 2000.

Sinninghe Damsté, J. S., Rijpstra, W. I. C., and Reichart, G. J.: The influence of oxic degradation on the sedimentary biomarker record II, Evidence from Arabian Sea sediments, Geochim. Cosmochim. Acta, 66, 2737-2754, 2002.

Sinninghe Damsté, J. S., Ossebaar, J., Abbas, B., Schouten, S., and Verschuren, D.: Fluxes and distribution of tetraether lipids in an equatorial African lake: Constraints on the application of the TEX $_{86}$ palaeothermometer and BIT index in lacustrine settings, Geochim. Cosmochim. Acta, 73, 4232-4249, 2009.

Sinninghe Damsté, J. S., Rijpstra, W. I. C., Hopmans, E. C., Weijers, J. W. H., Foesel, B. U., Overmann, J., and Dedysh, S. N.: 13,16-Dimethyl Octacosanedioic Acid (iso-Diabolic Acid), a Common Membrane-Spanning Lipid of Acidobacteria Subdivisions 1 and 3., Appl. Environ. Microbiol., 77, 4147-4154, 2011.

Steiner, D., Pauling, A., Nussbaumer, S. U., Nesje, A., Luterbacher, J., Wanner, H., and Zumbuhl, H. J. : Sensitivity of European glaciers to precipitation and temperature - two case studies, Climatic Change, 90, 413-441, 2008.

Thornalley, D. J. R., Elderfield, H., and McCave, I. N.: Holocene oscillations in temperature and salinity of the surface subpolar North Atlantic, Nature, 457, 711-714, 2009.

Tierney, J. E. and Russell, J. M.: Distributions of branched GDGTs in a tropical lake system: Implications for lacustrine application of the MBT/CBT paleoproxy, Org. Geochem., 40, 1032-1036, 2009.

Tierney, J. E., Russell, J. M., Eggermont, H., Hopmans, E. C., Verschuren, D., and Sinninghe Damsté, J. S.: Environmental controls on branched tetraether lipid distributions in tropical East African lake sediments, Geochim. Cosmochim. Acta, 74, 49024918, 2010a.

Tierney, J. E., Mayes, M. T., Meyer, N., Johnson, C., Swarzenski, P. W., Cohen, A. S., and Russell, J. M.: Late-twentieth-century warming in Lake Tanganyika unprecedented since AD 500, Nat. Geosci., 3, 422-425, 2010 b.

Tierney, J. E., Schouten, S., Pitcher, A., Hopmans, E. C., and Sinninghe Damsté, J. S.: Core and intact polar glycerol dialkyl glycerol tetraethers (GDGTs) in Sand Pond, Warwick, Rhode Island (USA): Insights into the origin of lacustrine GDGTs, Geochim. Cosmochim. Acta, 77, 561-581, 2012.

Toney, J. L., Huang, Y. S., Fritz, S. C., Baker, P. A., Grimm, E., and Nyren, P.: Climatic and environmental controls on the occurrence and distributions of long chain alkenones in lakes of the interior United States, Geochim. Cosmochim. Acta, 74, 15631578, 2010.

Trouet, V., Esper, J., Graham, N. E., Baker, A., Scourse, J. D., and Frank, D. C.: Persistent Positive North Atlantic Oscillation Mode Dominated the Medieval Climate Anomaly, Science, 324, 78-80, 2009.

Tyler, J. J., Nederbragt, A. J., Jones, V. J., and Thurow, J. W.: Assessing past temperature and soil $\mathrm{pH}$ estimates from bacterial tetraether membrane lipids: Evidence from the recent lake sediments of Lochnagar, Scotland, J. Geophys. Res.-Biogeosci., 115, G01015, doi:10.1029/2009JG001109, 2010.

Wanner, H. and Büttikofer, J. : Holocene Bond Cycles: real or imaginary? Geographie, 113, 338-349, 2008. 
Wanner, H., Solomina, O., Grosjean, M., Ritz, S. P., and Jetel, M.: Structure and origin of Holocene cold events, Quaternary Sci. Rev., 30, 3109-3123, 2011.

Weijers, J. W. H., Schouten, S., Hopmans, E. C., Geenevasen, J. A. J., David, O. R. P., Coleman, J. M., Pancost, R. D., and Sinninghe Damsté, J. S.: Membrane lipids of mesophilic anaerobic bacteria thriving in peats have typical archaeal traits, Environ. Microbiol., 8, 648-657, 2006a.

Weijers, J. W. H., Schouten, S., Spaargaren, O. C., and Sinninghe Damsté, J. S.: Occurrence and distribution of tetraether membrane lipids in soils: Implications for the use of the $\mathrm{TEX}_{86}$ proxy and the BIT index, Org. Geochem., 37, 1680-1693, 2006b.

Weijers, J. W. H., Schouten, S., van den Donker, J. C., Hopmans, E. C., and Sinninghe Damsté, J. S.: Environmental controls on bacterial tetraether membrane lipid distribution in soils, Geochim. Cosmochim. Acta, 71, 703-713, 2007a.

Weijers, J. W. H, Schefuss, E., Schouten, S., and Sinninghe Damsté, J. S.: Coupled thermal and hydrological evolution of tropical Africa over the last deglaciation, Science, 315, 1701-1704, $2007 b$.

Weijers, J. W. H., Panoto, E., van Bleijswijk, J., Schouten, S., Rijpstra, W. I. C., Balk, M., Stams, A. J. M., and Sinninghe Damsté, J. S.: Constraints on the Biological Source(s) of the Orphan Branched Tetraether Membrane Lipids, Geomicrobiol. J., 26, 402-414, 2009.
Wirth, S. B., Gilli, A., Niemann, H., Dahl, T.W., Lehmann, M. F., and Anselmetti, F. S.: Holocene flood frequency and redox-state evolution in meromictic Lake Cadagno (Swiss Alps), INQUACongress 2011.

Wirth, S. B., Gill, A., Dahl. T.W., Niemann, H., Ravasi, D., Sax, N., Lehmann, M.F., Peduzzi, R., Peduzzi, S., Tonolla, M., and Anselmetti, F.S.: 9800 years of meromixis in Lake Cadagno (Swiss Alps): Sedimentary evidence for initiation and persistency of euxinic conditions from heavy metal (Mn, Mo) and sulphur bacteria records, in preparation, 2012.

Zabeti, N., Bonin, P., Volkman, J. K., Jameson, I. D., Guasco, S., and Rontani, J.-F.: Potential alteration of $\mathrm{U}_{37}^{K^{\prime}}$ paleothermometer due to selective degradation of alkenones by marine bacteria isolated from the haptophyte Emiliania huxleyi, FEMS Microbiol. Ecol., 73, 83-94, 2010.

Zink, K.-G., Leythaeuser, D., Melkonian, M., and Schwark, L.: Temperature dependency of long-chain alkenone distributions in Recent to fossil limnic sediments and in lake waters, Geochim. Cosmochim. Acta, 65, 253-265, 2001.

Zink, K.-G., Vandergoes, M. J., Mangelsdorf, K., DieffenbacherKrall, A. C., and Schwark, L.: Application of bacterial glycerol dialkyl glycerol tetraethers (GDGTs) to develop modern and past temperature estimates from New Zealand lakes, Org. Geochem., 41, 1060-1066, 2010. 